\title{
ESTIMATION OF THE RECHARGE AREAS CONTRIBUTING WATER TO THE SOUTH WELL FIELD, COLUMBUS, OHIO
}

By Charles W. Schalk

U.S. GEOLOGICAL SURVEY

Water-Resources Investigations Report 96-4039

Prepared in cooperation with the CITY OF COLUMBUS, OHIO DIVISION OF WATER

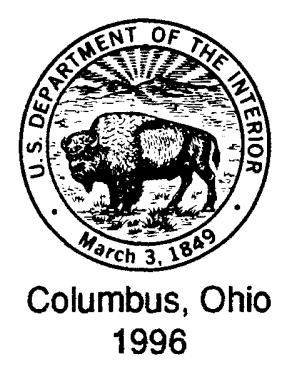




\section{U.S. DEPARTMENT OF THE INTERIOR BRUCE BABBITT, Secretary}

\section{U.S. GEOLOGICAL SURVEY}

Gordon P. Eaton, Director

For additional information write to:

District Chief

U.S. Geological Survey

975 West Third Avenue

Columbus, Ohio 43212-3192
Copies of this report can be purchased from:

USGS Branch of Information Services Box 25286

Denver, Colorado 80225 


\section{CONTENTS}

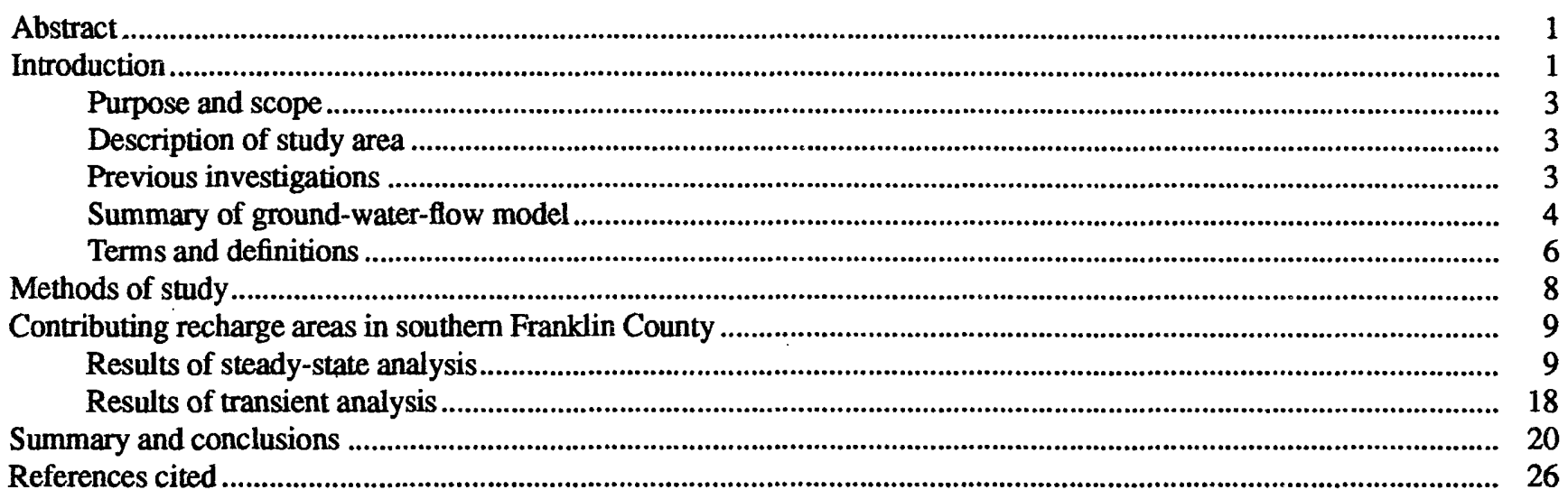

\section{FIGURES}

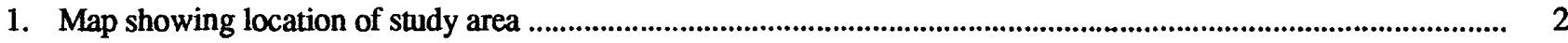

2. Model grid used to estimate areas contributing recharge in southern Franklin County, Ohio................................. 5

3. Map showing measured potentiometric surface of glacial-drift aquifer for (A) October 1979,

(B) March 1986, and (C) August 1988

4. Pictorial representation of terms relating to contributing recharge areas of a pumped well

5.-15. Maps showing:

5. Areas contributing recharge to selected discharge points under steady-state conditions, October 1979.

6. Areas contributing recharge to selected discharge points uner steady-state conditions, March 1986

7. Time-related contributing recharge areas of wells pumping 8 million gallons per day, March 1986

8. Time-related contributing recharge areas of wells pumping 16 million gallons per day, March 1986

9. Time-related contributing recharge areas of wells pumping 22 million gallons per day, March 1986

10. Loci of particles tracked from cells representing locations of Big Walnut Creek to cells representing locations on Scioto River, 1979 and 1986 steady-state simulations.

11. Time-related contributing recharge areas of wells between March 1986 and July 1991

12. Time-related contributing recharge areas of wells between March 1986 and July 1991, when simulated riverbed conductance was decreased by a factor of 10

13. Time-related contributing recharge areas of wells between March 1986 and July 1991, when simulated riverbed conductance was increased by a factor of 10 ....

14. Time-related contributing recharge areas of wells between March 1986 and July 1991, when simulated porosity of all aquifers was decreased 50 percent.

15. Time-related contributing recharge areas of wells between March 1986 and July 1991, when simulated porosity of all aquifers was increased 50 percent 
TABLES

1. Water budget for transient simulation, March 1986-June 1991

2. Effects of changes in simulated well-field-production rates on contributing recharge areas and lengths of intersected highways, 1986 steady-state simulation.

3. Traveltimes for particles started in cells representing Big Walnut Creek under four stress conditions, 1979 and 1986 steady-state simulations

4. Effects of changes in simulated vertical hydraulic and riverbed conductance on contributing recharge areas and related measurements (steady-state simulation, March 1986).

5. Effects of changes in simulated hydraulic conductivity, transmissivity, porosity, and recharge rates on contributing recharge areas and related measurements (steady-state simulation, March 1986)

CONVERSION FACTORS AND VERTICLE DATUM

\begin{tabular}{rll}
\hline Multiply & By & To obtain \\
\hline inch (in) & 25.4 & millimeter \\
inch per year $(\mathrm{in} / \mathrm{yr})$ & 25.4 & millimeter per year \\
foot $(\mathrm{ft})$ & 0.3048 & meter \\
mile $(\mathrm{mi})$ & 1.609 & kilometer \\
foot per mile $(\mathrm{ft} / \mathrm{mi})$ & 0.1894 & meter per kilometer \\
square mile $\left(\mathrm{mi}^{2}\right)$ & 2.590 & square kilometer \\
foot per day $(\mathrm{ft} / \mathrm{d})$ & 0.3048 & meter per day \\
gallon per day $(\mathrm{gal} / \mathrm{d})$ & 3.785 & liter per day \\
million gallons per day $(\mathrm{Mgal} / \mathrm{d})$ & 3,785 & cubic meter per day
\end{tabular}

Water and air temperatures in degrees Celsius $\left({ }^{\circ} \mathrm{C}\right)$ can be converted to degrees Fahrenheit $\left({ }^{\circ} \mathrm{F}\right)$ by the following equation: ${ }^{\circ} \mathrm{F}=1.8\left({ }^{\circ} \mathrm{C}\right)+32$

Sea level: In this report, "sea level" refers to the National Geodetic Vertical Daturn of 1929 (NGVD of 1929) - a geodetic datum derived from a general adjustment of the first-order level nets of both the United States and Canada, formerly called Sea Level Datum of 1929. 


\title{
Estimation of the Recharge Areas Contributing Water to the South Well Field, Columbus, Ohio
}

\author{
By Charles W. Schalk
}

\section{ABSTRACT}

The city of Columbus, Ohio, operates four radial collector wells, designed to yield $42 \mathrm{Mgal} / \mathrm{d}$ (million gallons per day), in southern Franklin County, Ohio, as part of their municipal supply of water. The collector wells are adjacent to, and designed to induce infiltration from, Big Walnut Creek and Scioto River. A previously constructed, three-dimensional, steady-state and transient ground-water-flow model of this river-aquifer system was used to estimate contributing recharge areas (CRA's) and calculate particle flowpaths in southern Franklin County. The simulations were of two steady-state periods (October 1979 and March 1986) and one 5-year transient period (March 1986-June 1991). The first simulation (1979) was of conditions before construction of the collector wells. The second simulation (1986) was of conditions when the collector wells were producing $8 \mathrm{Mgal} / \mathrm{d}$. During the 5 years covered in the transient simulation, production at the well field averaged $18.5 \mathrm{Mgal} / \mathrm{d}$.

Under the 1979 conditions, the largest ground-water contributing areas were of the quarries and Scioto River (41 and 47 percent of the study area, respectively). During 1986, when 8 $\mathrm{Mgal} / \mathrm{d}$ was withdrawn, the primary contributing areas were of the quarries ( 40 percent), collector wells ( 34 percent), and rivers ( 8 percent). Traveltimes associated with simulated particles of water tracked from cells along Big Walnut Creek to their discharge points in cells along Scioto River were about 5 to 60 years in the 1979 simulation and about 7 to 41 years in the 1986 simulation.
The endpoints of these particles varied as simulated pumping rates were increased to $22 \mathrm{Mgal} / \mathrm{d}$.

The 1986, 10-year CRA's of the collector wells under $8 \mathrm{Mgal} / \mathrm{d}$-conditions totalled about $4.5 \mathrm{mi}^{2}$. As the pumping rate was increased to 22 Mgal/d in a predictive simulation, 10-year CRA's of the collector wells increased to $6.7 \mathrm{mi}^{2}$.

Because the transient simulation encompassed only 5 years, the 10-year CRA's could not be estimated from the transient simulation. However, the size of the 1- to 5-year CRA's for the transient simulation was similar to the size of the 1- to 5-year CRA's for a steady-state predictive simulation if well-field production were $16 \mathrm{Mgal} / \mathrm{d}$. The transient simulations predicted discontinuous CRA's, especially adjacent to the rivers, due to changes in hydrologic stresses. Analyses of the steady-state and transient models showed that sizes of CRA's were most sensitive to changes in porosity, pumping rate, riverbed conductance, and horizontal hydraulic conductivity.

\section{INTRODUCTION}

The city of Columbus, Ohio, operates four radial collector wells in southern Franklin County (fig. 1). The aquifer at this "South Well Field" consists of permeable glacial outwash and ice-contact deposits intersected by Scioto River and Big Walnut Creek.

The wells were designed to yield $45.6 \mathrm{Mgal} / \mathrm{d}$ (million gallons per day) (Sedam and others, 1988); part of that amount was to result from induced infiltration of surface water. Average daily production from the well field in 1993 was about $20.4 \mathrm{Mgal} / \mathrm{day}$ (W. Eitel, city of Columbus, Division of Water, written commun., 1994), supplying 20-25 percent of the city's water. 

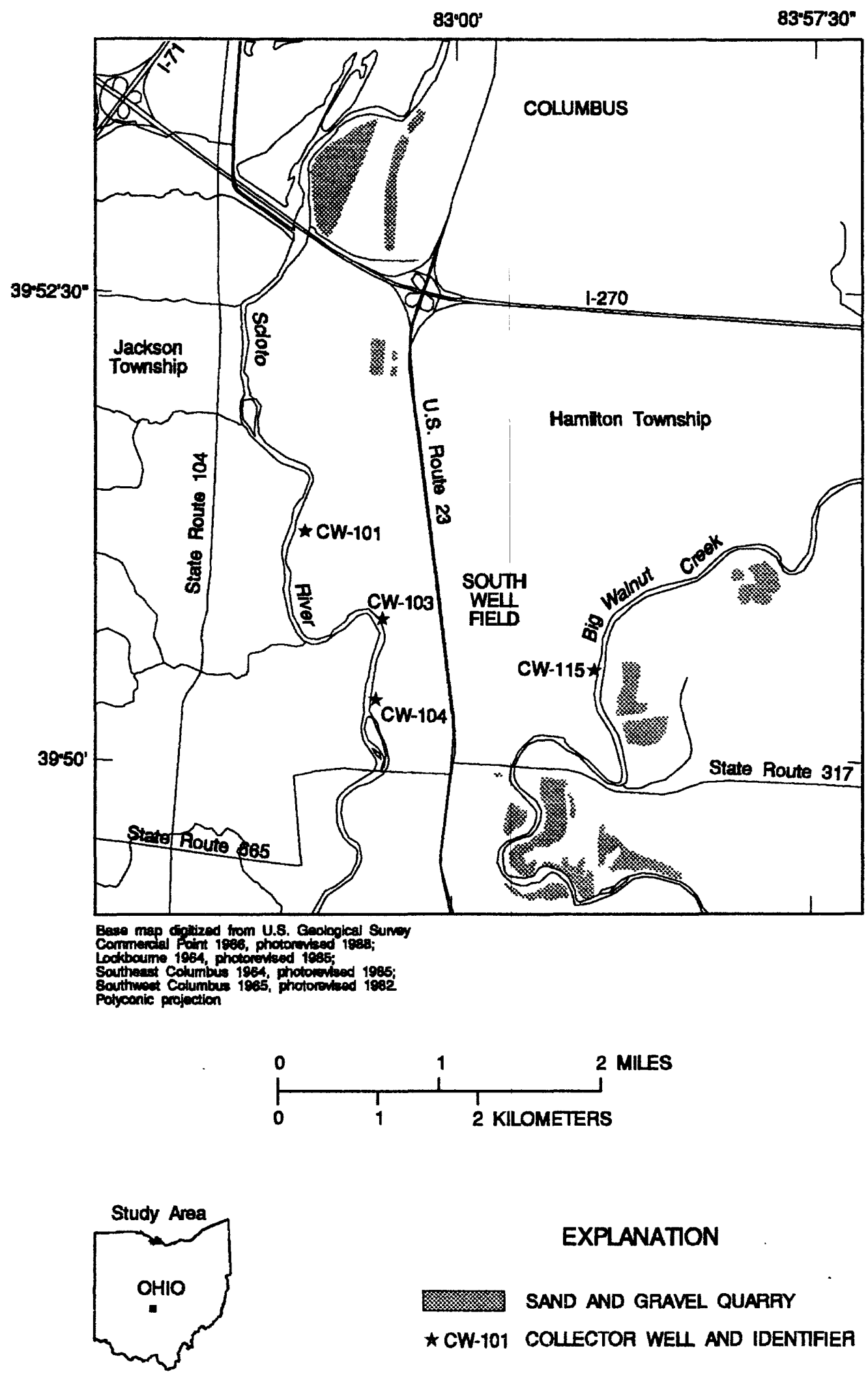

Figure 1. Location of study area. 
Columbus is pursuing actively a contributing-zone program to ensure a safe supply of water to its well field.

Ohio's wellhead-protection program states as its objective, "... to protect the health of people utilizing public drinking water by providing a focus zone around public wells or wellfields to prevent, detect and remediate ground water contamination" (Ohio Environmental Protection Agency, 1992, p. 6). Steps that should be taken to meet this objective include delineating a wellhead-protection area, identifying and managing potential pollution sources, and monitoring ground-water quality. Generally, wellhead-protection programs use traveltime-related contributing recharge areas (CRA's) (2-dimensional) rather than zones (3dimensional) based on the assumption that potential contamination sources are located at or near the land surface. These terms are defined in the section "Terms and Definitions."

\section{Purpose and Scope}

This report presents estimates of CRA's to the South Well Field under steady-state and transient conditions, based on simulations using a previously constructed ground-water-flow model (Cunningham and others, 1995). Previous work by Bair and others (1990) used steady-state conditions to estimate CRA's; the transient simulations described in this report provide improved estimates of CRA's because they incorporate the changes in hydrologic stresses that a steadystate simulation cannot address. After a review of the literature pertaining to the South Well Field, this report describes (1) the concept of CRA, (2) particle tracking as a means to determine CRA's, and (3) steady-state and transient CRA's and aquifer-stream interactions based on the results of the numerical ground-waterflow model. Included in the discussion of the CRA's are the effects of bedrock, quarries, and rivers on the predicted recharge areas. To parallel the work of Bair and others (1990), lengths of major highways intersected by the CRA's also are discussed.

\section{Description of Study Area}

The study area is in southem Franklin County, Ohio, in parts of Hamilton and Jackson Townships and the city of Columbus (fig. 1). The South Well Field, which is within the study area, includes three collector wells (CW-101, CW-103, and CW-104) along Scioto River and one (CW-115) along Big Walnut Creek.

The area is characterized by generally flat topography with slopes of 40 to $70 \mathrm{ft} / \mathrm{mi}$ toward the major streams. The primary industry in the study area is agriculture. Other industries include sand, gravel, and limestone quarries; commerce; and light manufacturing. Residential areas exist in the northeastern and southern parts of the study area. The glacial outwash is composed of very coarse sand and gravel ranging in thickness from 5 to $100 \mathrm{ft}$ (Schmidt and Goldthwait, 1958).

\section{Previous Investigations}

Much of the work concerning the exploration and development of water resources in southern Franklin County is described in reports from Ranney Water Systems (1970), Stilson and Associates (1976), and Malcolm Pimie (1988). Ranney Water Systems designed and built the radial collector wells of the South Well Field. The Malcolm Pirnie report (1988) discussed a well-field-protection plan for the city of Columbus.

Since 1980, the U.S. Geological Survey (USGS) has maintained an active role in studies relating to Columbus' ground-water supply. Included in the scope of USGS' participation were investigations into the hydrogeology of southern Franklin County (de Roche, 1985; Childress and others, 1991), water-quality assessments in relation to quarries and (or) landfill sites (de Roche and Razem, 1981, 1984; Sedam and others, 1989), and applications of simulated groundwater flow (Weiss and Razem, 1980; Razem, 1983; Sedam and others, 1989; Bair and others, 1990; Eberts and Bair, 1990; Childress and others, 1991). Sedam and others (1989) addressed the possibility of toxic spills on land near the well field reaching the water supply, basing their assessment on the results of a numerical flow model. They stated that spilled contaminants could enter the ground-water system directly by infiltration, but were more likely to drain overland into Scioto River and subsequently be drawn into the ground-water system by induced infiltration at the well field. Bair and others (1990) used a steadystate, three-dimensional numerical model and particle tracking to show simulated horizontal flow paths; 1,000-, 2,000-, and 3,000-day "capture areas" (this term is analogous to CRA, which is defined in "Terms and Definitions"); and flow-velocity vectors at loca- 
tions throughout the South Well Field. They discussed flowpaths and traveltimes from hypothetical spill sites (all on major highways) near the South Well Field. Particle endpoints depended greatly upon the production rate of the well field. Bair and others (1990) also showed that the 2,000-day capture area of the well field under maximum pumping rates (39 Mgal/d) was 30 percent larger and encompassed almost $4.5 \mathrm{mi}$ more highways than the capture area under normal pumping rates $(8 \mathrm{Mgal} / \mathrm{d})$.

The most recent USGS work concerning the hydrogeology of the study area and numerical modeling of the ground-water-flow system is described in Cunningham and others (1995). Their primary contributions to the hydrogeologic understanding of the area included the latest bedrock-topography map, geologic sections, and measurements of riverbed conductance at many locations along Scioto River and Big Walnut Creek. They described the construction and testing of the three-layer, transient numerical ground-water-flow model that was used in this study. Because the model developed by Cunningham and others (1995) was fundamental to the results described in this report, the reader should examine that report for full details concerning the transient numerical model. An overview of their model is presented in the next section.

\section{Summary of Ground-Water-Flow Model}

The model built by Cunningham and others (1995) contains 53 rows, 45 columns, and 3 layers and was constructed by use of the simulation code MODFLOW (McDonald and Harbaugh, 1988). The model grid (fig. 2), oriented nearly north-south, is variably spaced to account for availability of data and to simulate heads and hydraulic gradients accurately in specific areas of interest. The length and width of grid cells range from 200 to $2,000 \mathrm{ft}$ with finer spacings designed to increase detail in the areas near the collector wells. Finer grid spacing also allows for segregation of cells containing rivers and wells. There are 7,155 active grid cells.

The flow system is discretized vertically into three model layers. Layers 1 and 2 represent the glacial materials, and the boundary between the two does not necessarily follow a geologic discontinuity. Layer 1 extends from the water table to a depth of approximately $15 \mathrm{ft}$, but is absent (mined out) at a bedrock quarry on the northem boundary of the study area. This layer contains Scioto River and Big Walnut
Creek and allows the rivers and tributaries to partially penetrate a thin model layer, thereby increasing the vertical resolution of the model. At the collector wells, the thickness of layer 1 is increased, allowing the well to fully penetrate model layer 2 . Layer 2 includes the remainder of the saturated glacial drift and ranges in thickness from $0 \mathrm{ft}$ in the bedrock quarry at the northern boundary of the study area to $95 \mathrm{ft}$ on the northeastem boundary of the study area. The bottom of layer 2 coincides with the top of bedrock in the study area. Layer 3 includes all of the bedrock in the study area to an elevation of $250 \mathrm{ft}$ above sea level and can be up to $375 \mathrm{ft}$ thick. The bottom of layer 3 is a noflow boundary.

The glacial outwash deposits were modeled as one major unconsolidated aquifer with spatial variations in hydraulic properties as determined from aquifer tests and well logs. The upper two layers of the model were assigned horizontal hydraulic conductivities ranging from 30 to $375 \mathrm{ft} / \mathrm{d}$ and thicknesses depending upon the depth to the bedrock surface. The specific yield of layer 1 ranges from 0.12 to 0.3 , as determined from aquifer tests, published values for unconsolidated materials (Johnson, 1967), and model calibration. Specific storage of the glacial deposits in layer 2 was $0.000075 \mathrm{ft}$.

Also simulated by the model is flow in the upper part of the carbonate bedrock aquifer that underlies the glacial outwash. Horizontal hydraulic conductivity was modeled as 10 to $15 \mathrm{ft} / \mathrm{d}$ in the carbonate bedrock aquifer. The storage coefficient of model layer 3 was set at a constant value of 0.0002 on the basis of published values from the carbonate bedrock aquifer in Franklin County (Schmidt and Goldthwait, 1958); this value is higher than that of the glacial material (layer 2) because of the thickness of the bedrock in layer 3 .

Ground water at the South Well Field is recharged by precipitation, regional ground-water flow, and induced stream infiltration. Simulated recharge rates varied spatially and ranged from 4.0 to $12.0 \mathrm{in} / \mathrm{yr}$, although recharge was set to $0 \mathrm{in} / \mathrm{yr}$ for stress periods simulating seasons of prolonged drought.

Previous studies indicate that streambed permeability is a sensitive parameter in this flow system (Sedam and others, 1989; Childress and others, 1991). Gain/loss studies, seepage-meter tests, and riverinesetting maps of Scioto River and Big Walnut Creek were used to estimate streambed conductivities for the flow model. These permeability data are reported in 


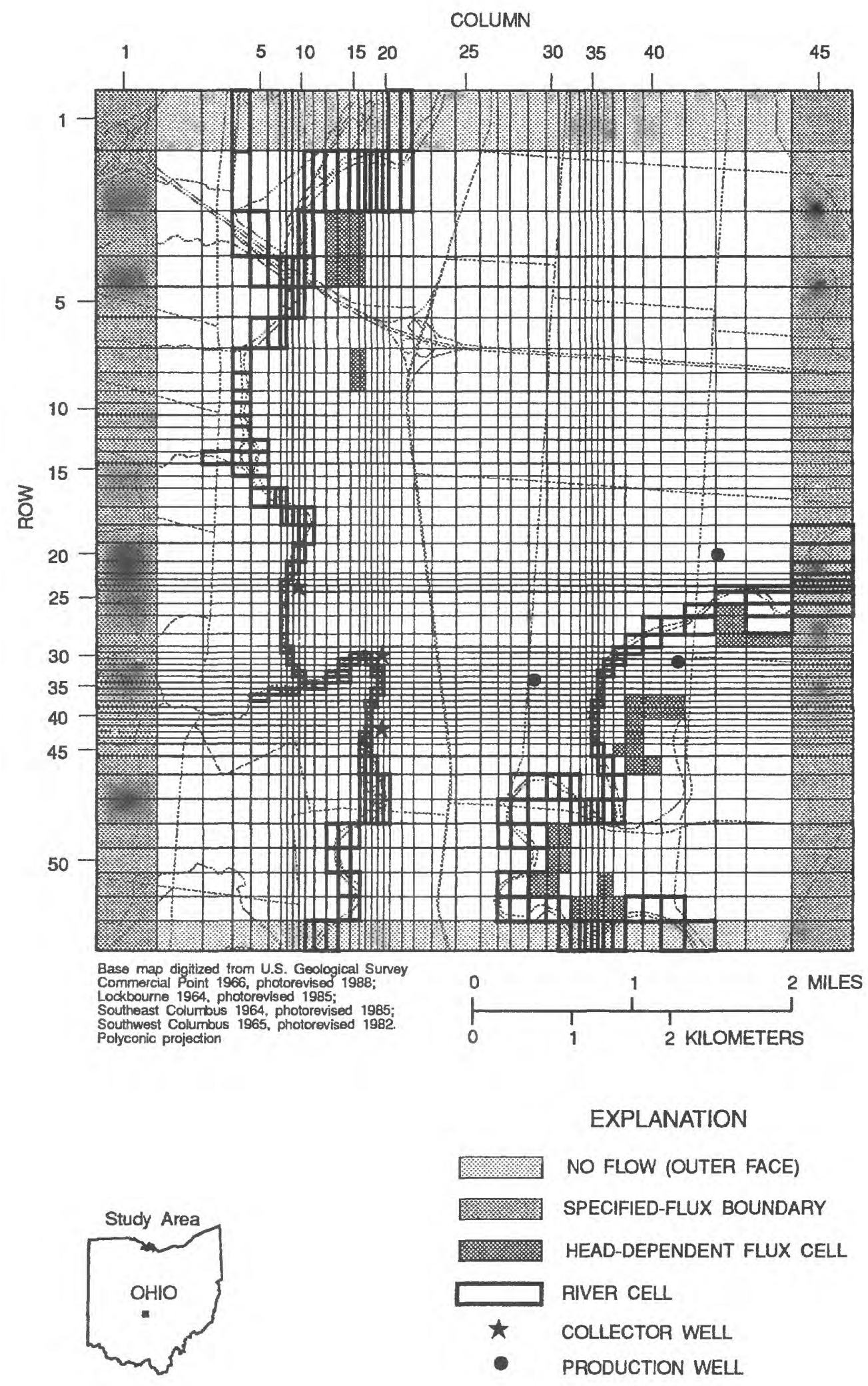

Figure 2. Model grid used to estimate areas contributing recharge in southern Franklin County, Ohio. (From Cunningham and others, 1995.) 
Childress and others (1991), Moreno (1988), and Cunningham (1992). Rivers and their tributaries in the study area were simulated as head-dependent fluxes.

Pumping in the bedrock quarry on the northern boundary of the study area (fig. 2) dewaters the area to an elevation of $562 \mathrm{ft}$ above sea level. This dewatering is simulated by assigning specified heads of $562 \mathrm{ft}$ to the cells in layer 3 that correspond to the sump pit in the quarry. The gravel quarries in the central and southeastern part of the study area are simulated by head-dependent fluxes. Other pumpage within the study area is simulated as specified fluxes.

Measured heads from October 1979 were used as steady-state calibration targets for the period before the collector wells were constructed. Measured heads from March 1986 were used as steady-state calibration targets for the period after commencement of pumping at the collector wells because well-field pumpage had been at nearly the same rate for several years. Simulated heads from the March 1986 steady-state calibration were used as the starting heads for transient simulation. Transient model calibration was based on seven sets of hydraulic-head measurements made from March 1986 through June 1991. This time period includes large-scale increases in well-field production associated with a drought in the summer of 1988 and a period of exceptionally high rainfall in 1990. Distributions of measured hydraulic heads in the glacial-drift aquifer are shown in figure 3 for October 1979, March 1986, and August 1988, respectively. For the transient model, time was discretized into 8 stress periods from 93 to 487 days on the basis of recharge, well-field pumpage, and available water-level measurements for calibration targets.

The steady-state and transient calibrations were evaluated by visually comparing contour maps of simulated and measured heads in each model layer and by minimizing values of the mean absolute error (MAE) and root mean square error (RMSE), which are statistical computations of differences between measured and simulated heads. In addition, measured hydrographs from wells with water-level data available during the entire simulation period were compared visually with simulated hydrographs over the same period.

The water balance for the transient simulation indicates that the average well-field production was 18.5 Mgal/d (table 1). Because the simulation began and ended under similar hydrologic conditions, the balance for the entire simulation indicates little change
Table 1. Water budget for transient simulation, March 1986-June 1991

[Flow rates in million gallons per day. From Cunningham and others, 1995]

Flow to aquifer from:

Storage

Flow rate

Boundary flow

3.4

Recharge

18.1

River leakage

8.9

Quarries

14.3

Total in:

49.0

Flow from aquifer to:

Storage

Wells

18.5

River leakage

5.0

Bedrock quarry

19.5

Quarries

2.7

Total out:

49.0

Percent discrepancy

of in-out calculations:

0.0

in storage. The major inflows to the aquifer were boundary flow, river leakage, and areal recharge. Major outflows were to the collector wells and the bedrock quarry.

\section{Terms and Definitions}

The concepts of contributing area and related terms, illustrated in figure 4, are described in detail by Morrissey (1989) and Reilly and Pollock (1993). In the case of an unconfined aquifer, the cone of depression of a pumped well is that aquifer volume that is drained in response to the withdrawal of water. In the case of a confined aquifer, the cone of depression is the difference between the prepumping position of the potentiometric surface and the postpumping position of the potentiometric surface. The area of influence of a pumped well is the land area that directly overlies and has the same horizontal extent as the part of the potentiometric surface that is perceptibly lowered by the withdrawal of water (Meinzer, 1923). The area of influence is a two-dimensional projection of the cone of depression on the land surface. The zone of contri- 

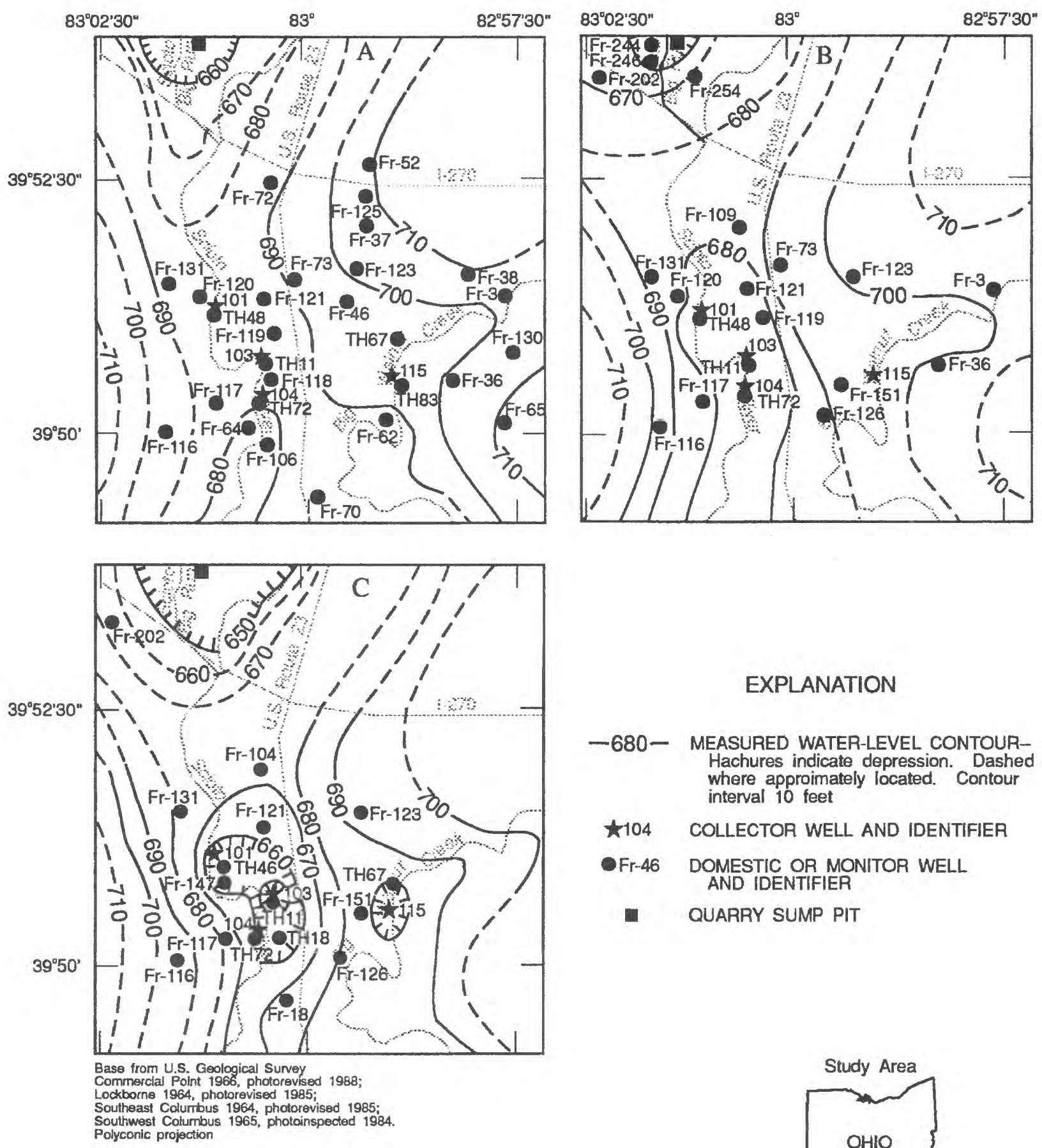

$\downarrow 104$ COLLECTOR WELL AND IDENTIFIER

- Fr-46 DOMESTIC OR MONITOR WELL AND IDENTIFIER

QUARRY SUMP PIT
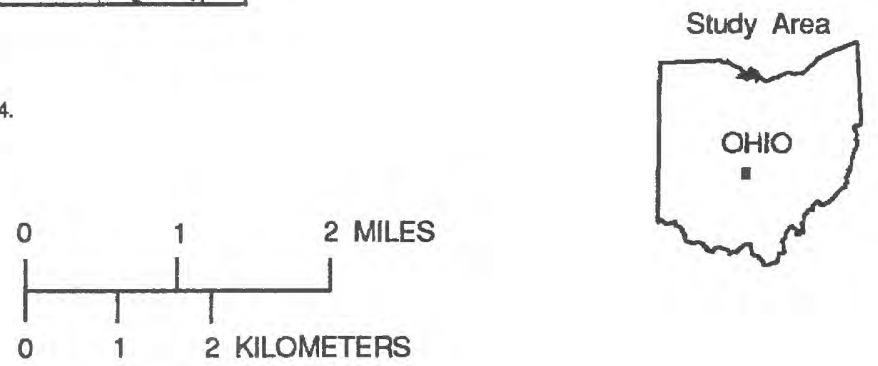

Figure 3. Measured potentiometric surface of glacial-drift aquifer for (A) October 1979, (B) March 1986, and (C) August 1988. (From Cunningham and others, 1995). 


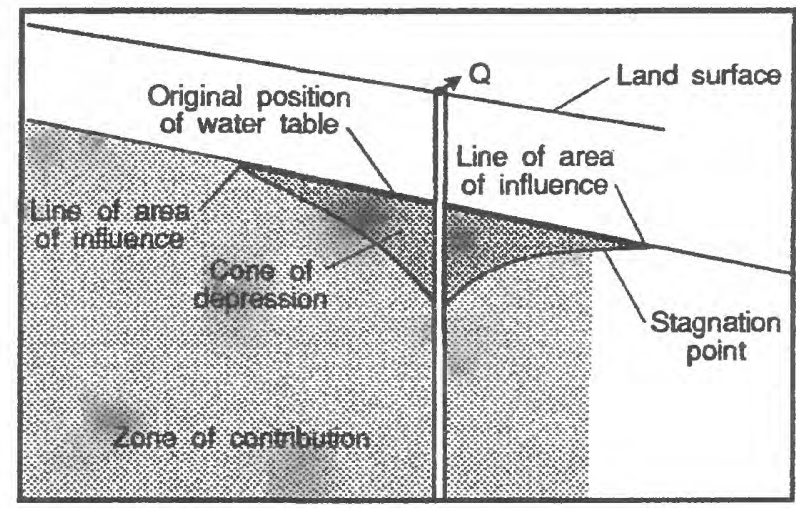

From Morrissey, 1999

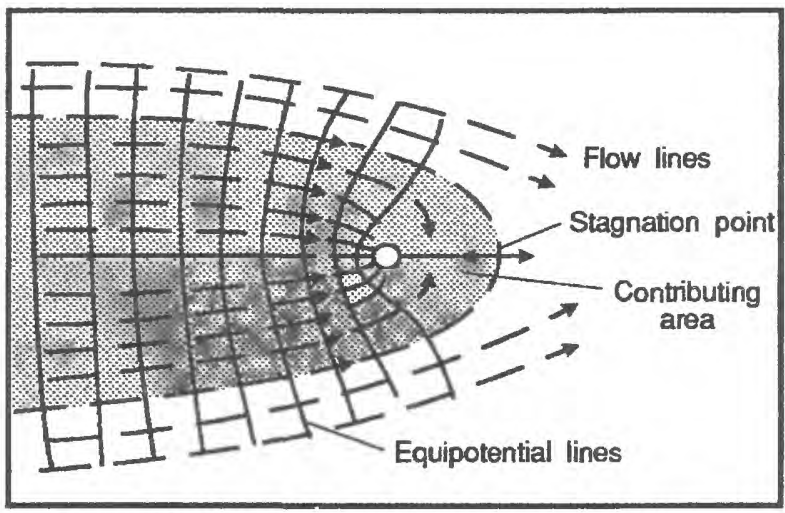

From Morrissey, 1899

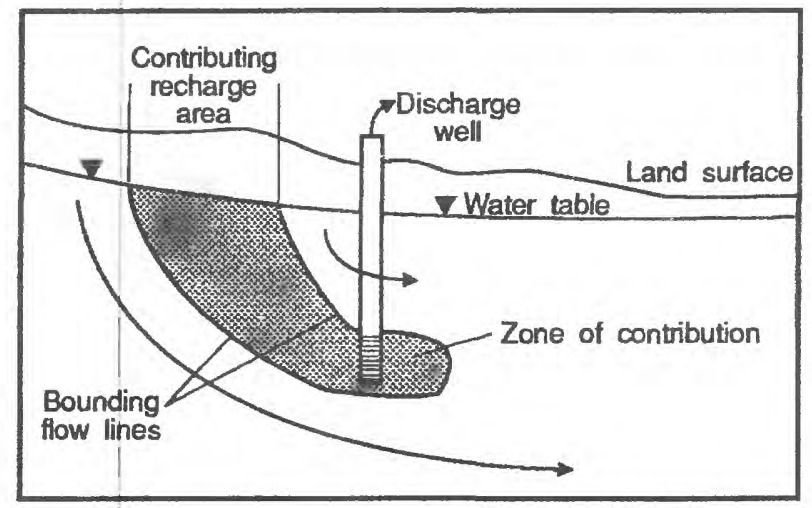

Modified from Rolly and Pollock, 1993

PLAN VIEW

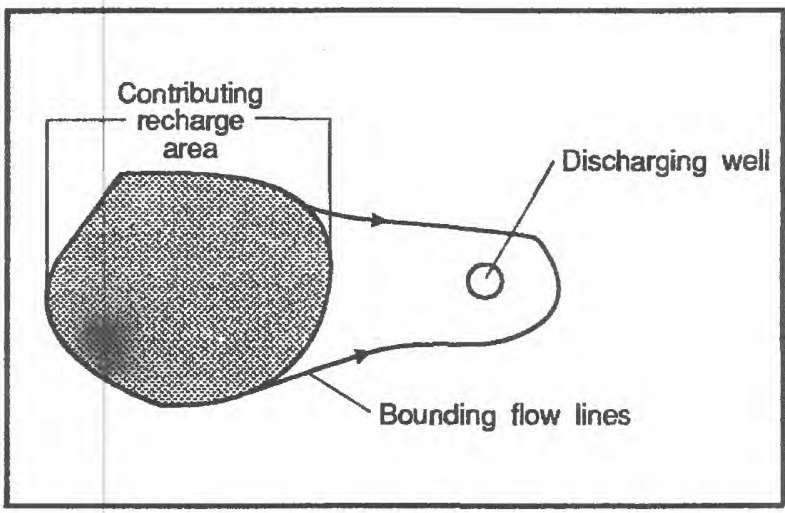

Modified from Relly and Pollock, 1993

Figure 4. Pictorial representation of terms relating to contributing recharge areas of a pumped well.

bution of a pumped well is "the volumetric portion of an aquifer from which ground-water flow is diverted by a pumping well" (Morrissey, 1989, p. 8). The contributing area of a pumped well is "the land area that has the same horizontal extent as that part of an aquifer, or adjacent areas, from which ground-water flow is diverted to the pumping well" (Morrissey, 1989, p. 8). The contributing area for a pumped well is a twodimensional projection of the zone of contribution on the land surface. The contributing recharge area (CRA) of a pumping well is the surface area that defines the location of the water entering the groundwater system at the water table, flowing to the well, and discharging from the well (Reilly and Pollock, 1993; Sheets, 1994). Finally, the traveltime-related CRA is the surface area that defines the location of the water that enters the ground-water system at the water table, flows to the well, and discharges from the well within a specified time period.

\section{METHODS OF STUDY}

The particle-tracking algorithm used in this study to determine the CRA's was MODPATH (Pollock, 1994). MODPATH is a semi-analytical particletracking program developed by the USGS that can predict steady-state or transient flowpaths by tracking hypothetical particles of water forward or backward through a simulated flow field. The calculations of MODPATH are based on the assumption that each directional velocity component varies linearly within a grid cell in its own coordinate direction. Average lin- 
ear velocity across each face in a cell is obtained from the volume flow rate, cross-sectional area of the cell, and effective porosity of the material in the cell.

MODPATH uses MODFLOW output (hydraulic heads and cell-by-cell flows) and input files during its computations.

Results from particle-tracking exercises were analyzed by use of a geographical information system (GIS). Relative locations of particles were converted into real-world coordinates corresponding to the study area, and traveltimes were added as attribute data; from these data, traveltime-related CRA's and flowpaths were estimated.

Ground-water-flow models constructed by Cunningham and others (1995) were used to examine CRA's and traveltimes under three scenarios: conditions in October 1979, before pumping began (a steady-state simulation); conditions in March 1986, after the wells had been pumping steadily at $8 \mathrm{Mgal} / \mathrm{d}$ for several years (a steady-state simulation); and conditions between March 1986 and June 1991, when well-field production and aquifer recharge were highly variable (a 5-year transient simulation). The October 1979 simulation was considered indicative of "historical" conditions. The March 1986 steady-state simulation was used to predict CRA size and configuration under "predictive" well-field withdrawals of 16 and 22 Mgal/d. CRA's under the 1986 steady-state and 1986-91 transient simulations were examined for sensitivity to systematic changes in hydrogeologic parameters.

Two measurements are used to describe the CRA's and their implications on the study area: the sizes of the CRA's, reported in square miles; and the length of major highways (interstate, state, and federal routes) crossing the CRA's. The latter is included in the analyses because point-source pollution of the well field probably would begin at or near land surface along the major highways; also, these data provide some comparison with the findings of Bair and others (1990).

\section{CONTRIBUTING RECHARGE AREAS IN SOUTHERN FRANKLIN COUNTY}

As stated earlier, prediction of CRA's by MODPATH requires hydraulic head and cell-by-cell flow information from MODFLOW and values of effective porosity for each cell. Effective porosity used in this study ranged from 0.10 to 0.25 in the glacial materials (layers 1 and 2) and was 0.30 in the bedrock (layer 3 ). Generally, the effective porosity of a formation is marginally higher than the specific yield of the formation; however, in this study, the porosity of the glacial materials was assumed to be equal to the specific yield of glacial materials, which were derived from aquifer tests and (or) published values of unconsolidated materials (Johnson, 1967). Discussion of the effects of ranges of porosity on the sizes of predicted CRA's is presented later in this report.

\section{Results of Steady-State Analysis}

Most of the results of the steady-state analysis confirm the results of Bair and others (1990), which were discussed in the section concerning previous investigations. The results of this study are not identical to the results of Bair and others (1990) because of new information on hydraulic conductivity, streambed permeability, and other hydrogeologic factors that was incorporated into this study.

Areas contributing recharge to Scioto River, Big Walnut Creek, and quarries active during 1979 are shown in figure 5 . Of the $25 \mathrm{mi}^{2}$ included in the modeled area, $9.5 \mathrm{mi}^{2}$ ( 38 percent) contribute water to the quarry at the north end of the study area; $11.7 \mathrm{mi}^{2}$ (47 percent) contribute water to Scioto River; $2.9 \mathrm{mi}^{2}(12$ percent) contribute water to Big Walnut Creek; and 0.9 $\mathrm{mi}^{2}$ ( 3 percent) contribute water to quarries at the south end of the study area. Thus, under "historical" conditions, more than two-fifths of the land surface encompassed in the study area provided recharge to quarries, and the rest provided flow to the rivers.

Much of the modeled reach of Big Walnut Creek loses water to the underlying aquifer. About 58 percent of the length of Big Walnut Creek is included in the CRA of Scioto River because of downward hydraulic gradients through the riverbed. The altitude of the bed of Scioto River is lower than that of Big Walnut Creek, providing the downward gradient. These model results support the hydrologic data collected during the study (Cunningham and others, 1995).

Steady-state CRA's of all discharge points in the study area for March 1986 (when the well field was producing $8 \mathrm{Mgal} / \mathrm{d}$ ) are shown in figure 6 . Note that steady-state CRA's are drawn under the assumption that hydrologic conditions and stresses remain 

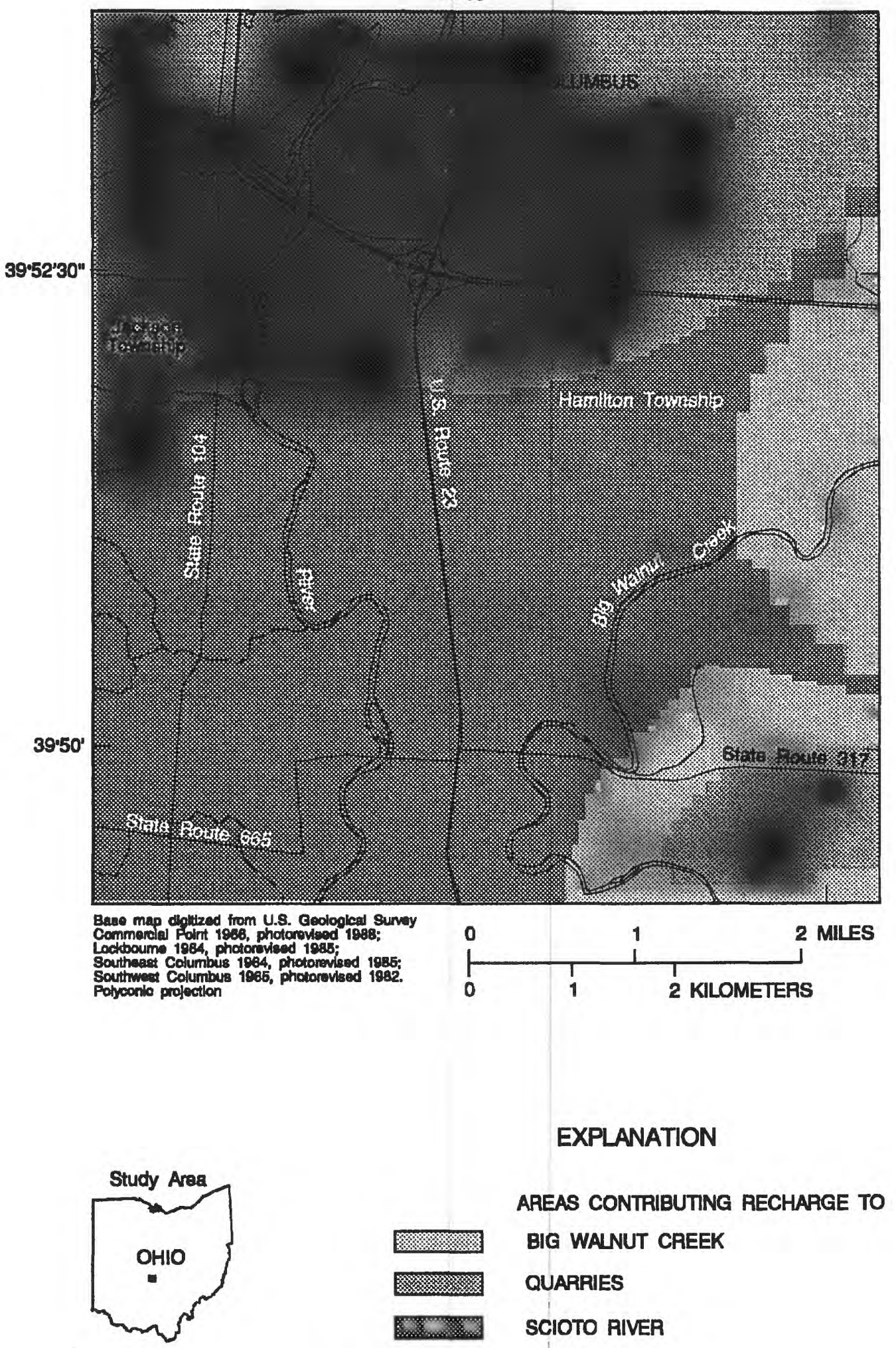

AREAS CONTRIBUTING RECHARGE TO BIG WALNUT CREEK

QUARPIES

SCIOTO RIVER

Fgure 5. Areas contributing recharge to selected discharge points under steady-state conditions, October 1979, southern Franklin County, Ohio. 


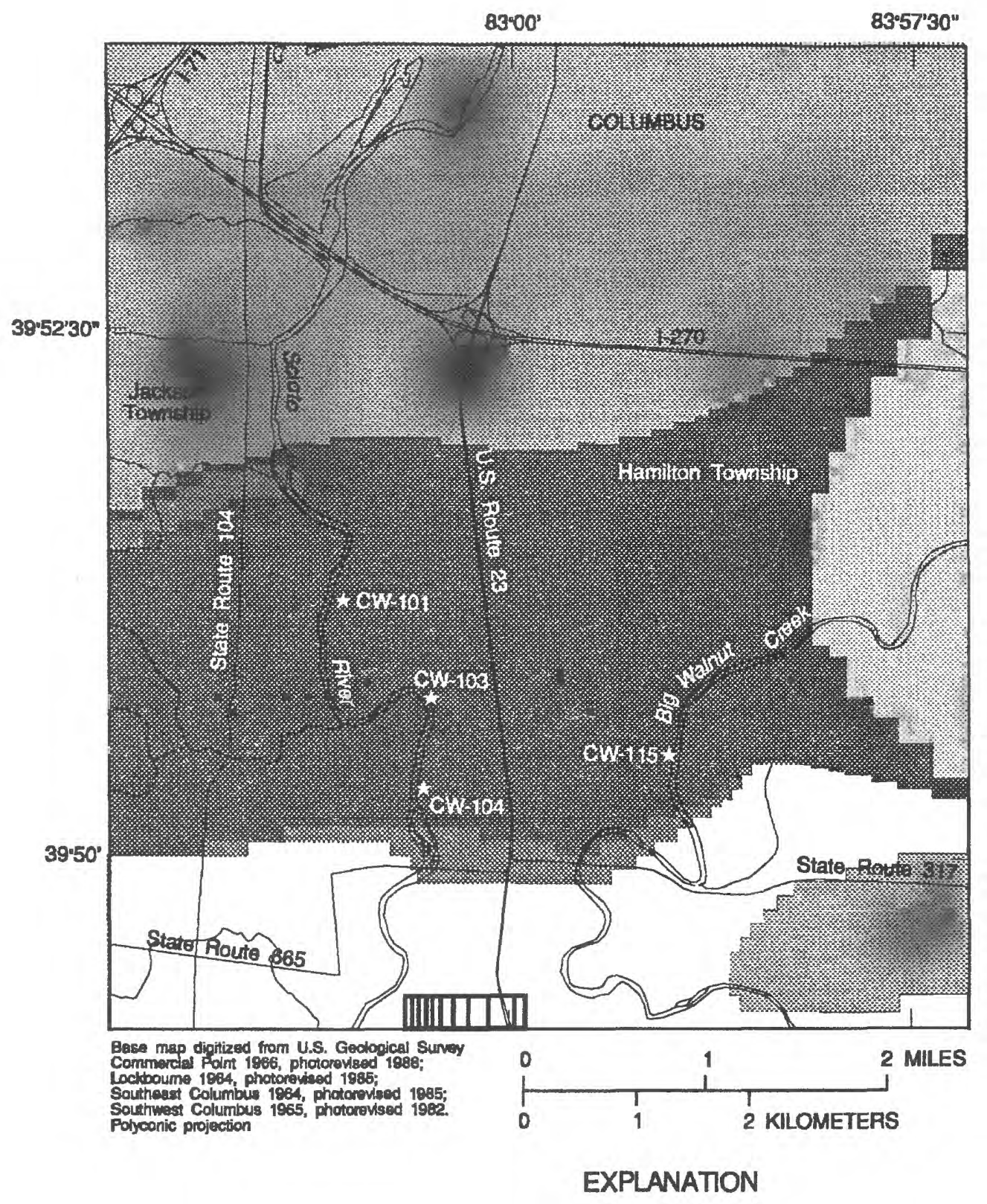

AREAS CONTRIBUTING RECHARGE TO

BIG WALNUT CREEK

W... QUARPIES
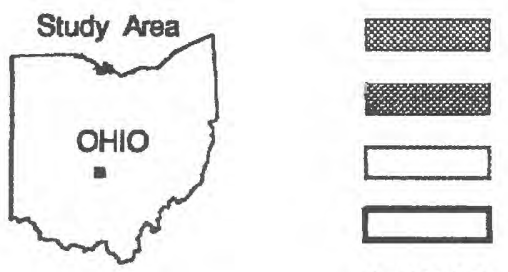

SCIOTO RIVER

COUECTOR WEUS

TEMPORARY DEWATERING OPERATION

TEMPORARY DEWATERING OPERATION CELL

$\star$ CW-101 COLECTOR WEL AND IDENTIFIER

Figure 6. Area contributing recharge to selected discharge points under steady-state conditions, March 1986, southern Franklin County, Ohio. 
unchanged, which is not always the case. For example, a temporary dewatering operation (active from about 1985 through 1988 and discussed in Cunningham and others, 1995) near the south end of the study area had a steady-state CRA that occupied about 16 percent of the study area; however, because of the brevity of the operation, the dewatering wells did not actually draw water from 16 percent of the study area during the operation. The CRA of Scioto River decreased from 47 percent of the study area in 1979 to 2 percent of the study area in 1986. Most of what had contributed recharge to Scioto River in 1979 was contributing recharge to the collector wells and the temporary dewatering operation in 1986; CRA's of the collector wells totaled about 34 percent of the study area. CRA's of quarries and Big Walnut Creek were about 40 and 6 percent of the study area, respectively.

The 1-, 5-, and 10-year CRA's of the collector wells when the well field was producing $8 \mathrm{Mgal} / \mathrm{d}$ (March 1986) are shown in figure 7. The CRA's for the collector wells pumping under predictive conditions (16 and $22 \mathrm{Mgal} / \mathrm{d}$ ) are shown in figures 8 and 9. Sizes of CRA's and lengths of major roads affected under each pumping scenario are listed in table 2 .

Under all three pumping stresses, the CRA's for three of the four wells are elongated primarily toward the northeast; only the CRA for CW-101 extends more to the west than to the east. In all three simulations, the areal extent of the 5- to 10-year CRA is influenced by the western boundary of the modeled area, most noticeably in the 16- and 22-Mgal/d simulations. Extending the model boundary to the west to accommodate the CRA of CW-101 results in several possible scenarios. First, the CRA could extend further west than is shown and be larger than reported in table 2 . However, the aquifer materials west of the study area are fine-grained glacial tills, carbonates, and shales, and their permeabilities are notably lower than those of the glacial drift materials at the well field. Second, the CRA could extend further toward the north and east of CW-101, where the coarse-grained sand and gravel deposits are. This result was seen during simulations by Sheets (1994) in a geohydrologic setting similar to that in southern Franklin County; given coarse-grained, highly permeable materials at a great distance from the pumped well and fine-grained, poorly permeable materials near the well, the CRA of the well extended toward the more permeable materials. Third, the CRA could respond in a combination of the two alternatives described above; and this scenario is most probable. Whether this change would affect significantly the lengths of major roads intersected by the 5- to 10-year CRA is doubtful. The nearest major road west of State Route 104 is Interstate 71, about 2.5 mi away, and the 5- to 10-year CRA would not extend that far.

The CRA's increased in size with increases in well-field production. From 8 to $16 \mathrm{Mgal} / \mathrm{d}$, most of the increase in CRA size and road length intersected came from areas contributing to the collector wells along Scioto River (CW-101, CW-103, and CW-104). From 16 to $22 \mathrm{Mgal} / \mathrm{d}$, however, most increases in CRA sizes came from areas contributing to $\mathrm{CW}-115$, along Big Walnut Creek. This effect on the CRA of CW-115 develops because the distribution of withdrawals during the 22-Mgal/d simulation were

Table 2. Effects of changes in simulated well-field-production rates on contributing recharge areas and lengths of intersected highways, 1986 steady-state simulation

[CRA, contributing recharge area]

\begin{tabular}{|c|c|c|c|c|c|c|}
\hline \multirow{3}{*}{$\begin{array}{l}\text { CRA time, in } \\
\text { years }\end{array}$} & \multicolumn{3}{|c|}{ CRA size, in square miles } & \multicolumn{3}{|c|}{$\begin{array}{l}\text { Length of major highways intersected by } \\
\text { CRA, in miles }\end{array}$} \\
\hline & \multicolumn{6}{|c|}{ Differences in response to variability in production rate, in million gallons per day } \\
\hline & 8 & 16 & $\underline{22}$ & $\underline{8}$ & 16 & $\underline{22}$ \\
\hline $0-1$ & 0.48 & 0.94 & 1.16 & 0.00 & 0.00 & 0.00 \\
\hline $1-5$ & 1.90 & 2.97 & 3.18 & 2.06 & 4.18 & 5.03 \\
\hline $5-10$ & 2.12 & 2.41 & 2.32 & 1.20 & 1.85 & 1.56 \\
\hline
\end{tabular}




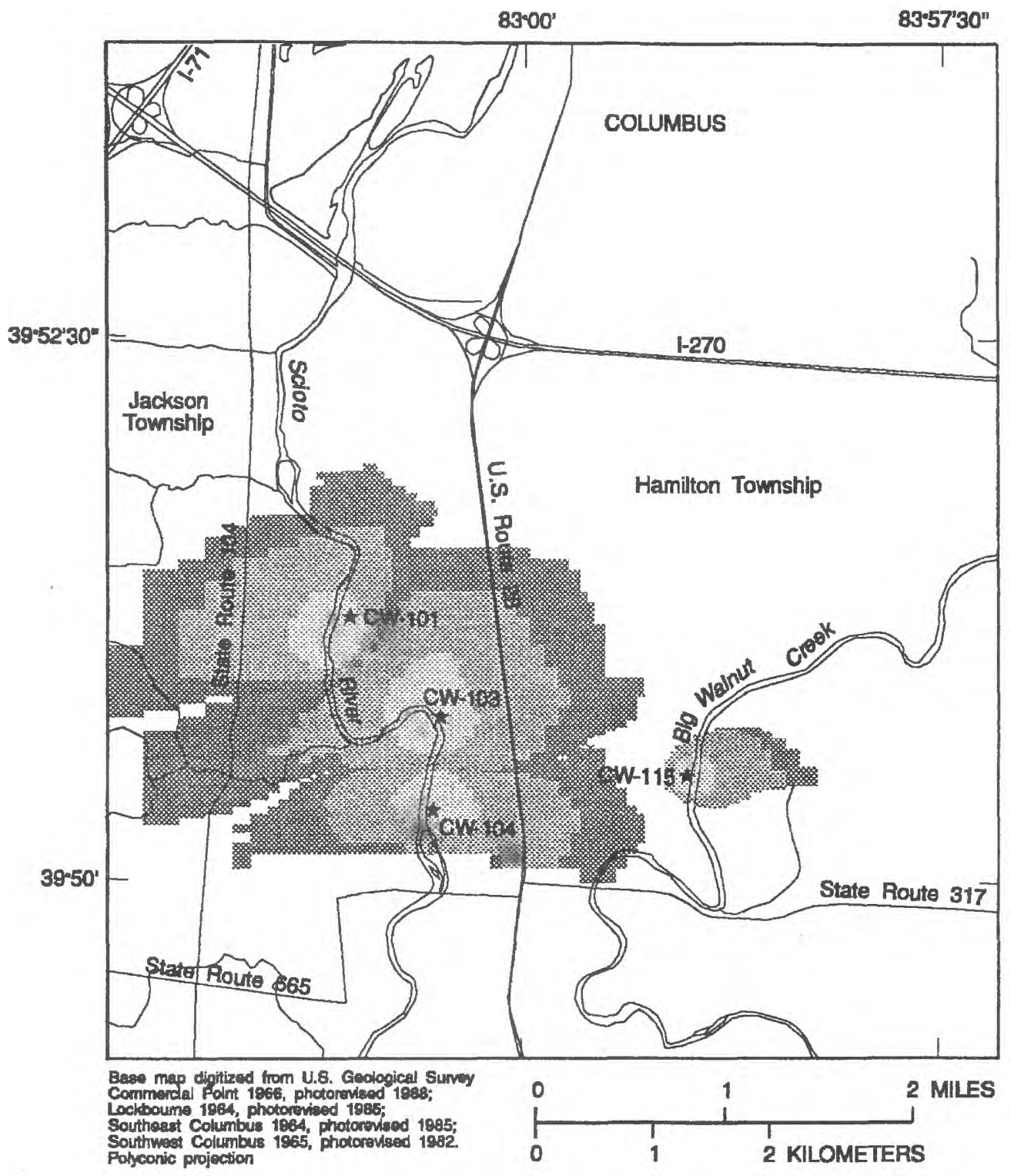

EXPLANATION

AREAS CONTPIBUTING RECHARGE TO COLECTOR WELS

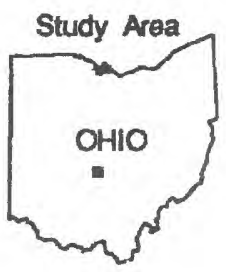

$0-1$ YEAR
1-5 YEAR
5-10 YEAR
$\star C W-101$ COUECTOR WEL AND IDENTIFIER

Fgure 7. Time-related contributing recharge areas of wells pumping 8 million gallons per day, March 1986, southem Franklin County, Ohio. 


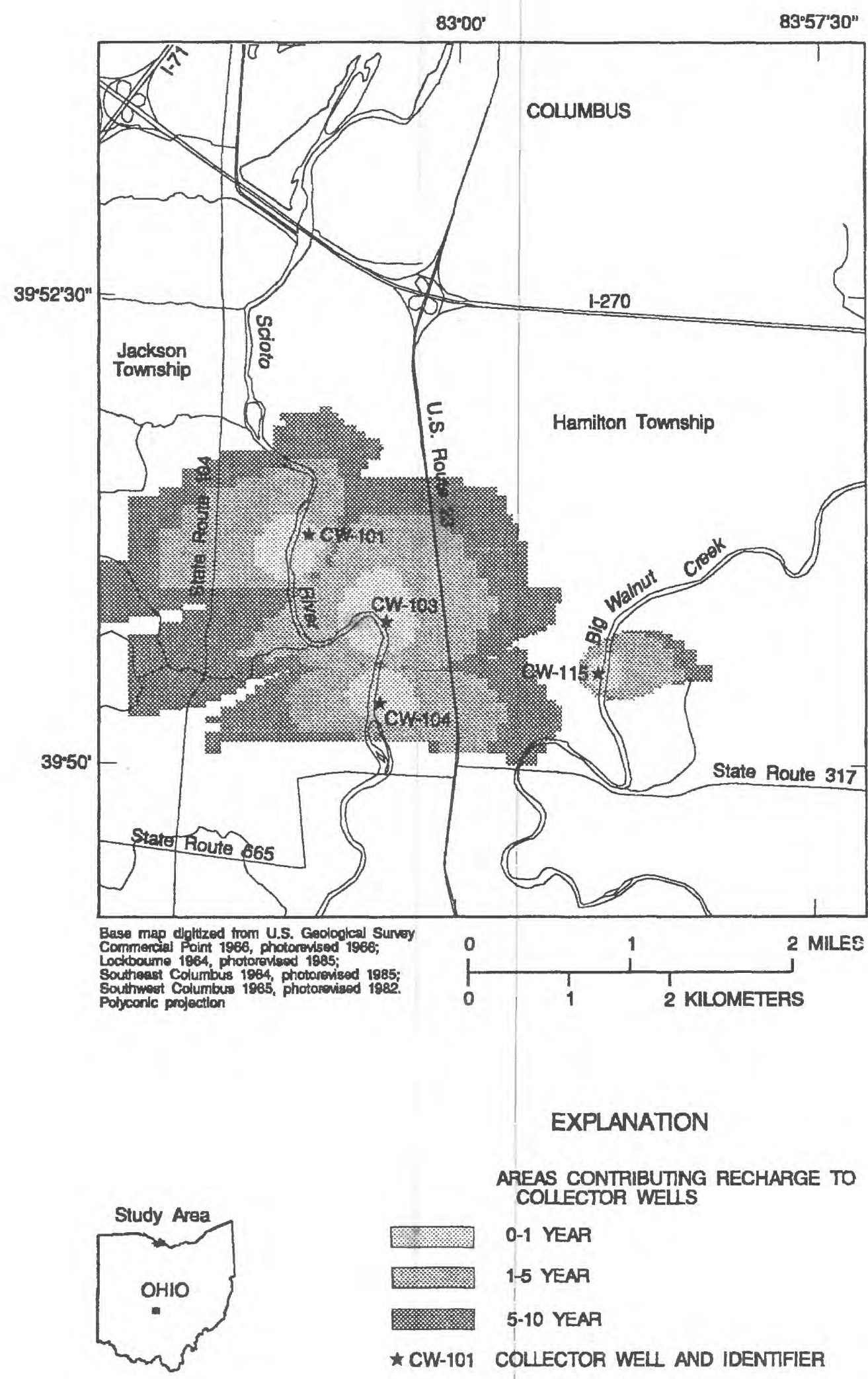

Figure 8. Time-related contributing recharge areas of wells pumping 16 million gallons per day, March 1986, southern Franklin County, Ohio. 


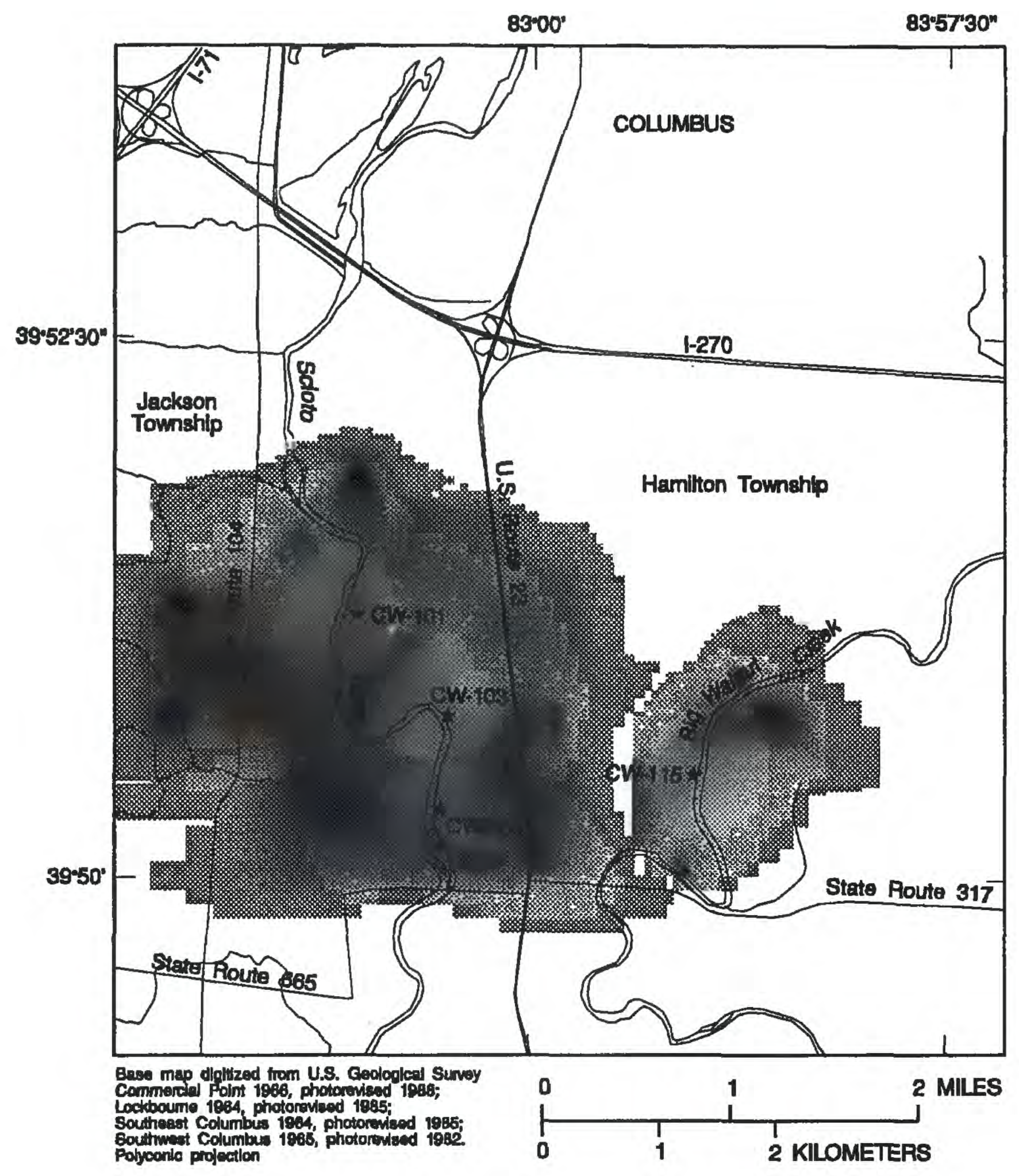

EXPLANATION

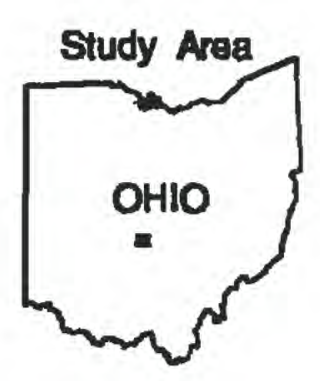

AREAS CONTRIBUTING RECHARGE TO COLLCTOR WELS

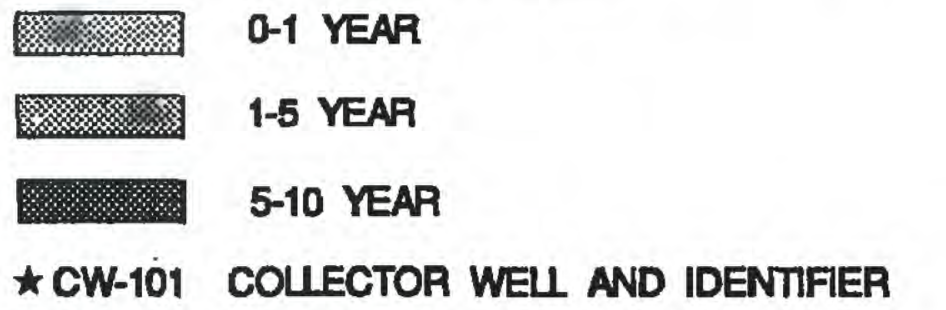

Figure 9. Time-related contributing recharge areas of wells pumping 22 million gallons per day, March 1986, southern Franklln County, Ohlo. 
weighted toward $\mathrm{CW}-115$ (which is the distribution expected by the city of Columbus; W.L. Cunningham, U.S. Geological Survey, written commun., 1996), thereby resulting in a disproportionately larger increase in its CRA from 16 to $22 \mathrm{Mgal} / \mathrm{d}$. Because CW-115 is not adjacent to any major roads, the growth of its CRA from 16 to $22 \mathrm{Mgal} / \mathrm{d}$ did not incorporate any additional length of roads. Total 0 - to 10-year CRA increased only slightly between 16 and $22 \mathrm{Mgal} /$ $\mathrm{d}$ because of boundary effects at the western edge of the study area.

Simulated particles (nine in each cell) were started at the water table in six cells representing various reaches of Big Walnut Creek for each of the four steady-state scenarios (fig. 10). In the 1979 simulation, all these particles were shown to discharge into Scioto Riyer at or below the current location of CW-104. The shortest traveltime associated with the particle tracks is about 4.9 years, and the longest traveltime about 60 years. At the 8-Mgal/d rate, particles that began in the southermmost cells discharged into the same cells along Scioto River as they did when the wells were not pumping; however, several of the particles entered the discharge cell from the west because they were influenced by pumping at CW-104. Particles at the same starting location all discharge to CW-104 in the 16and 22-Mgal/d simulations.

Particles that were placed in cells representing a location about $1,200 \mathrm{ft}$ south of $\mathrm{CW}-115$ discharged to Scioto River in the no-pumping simulation; to CW-

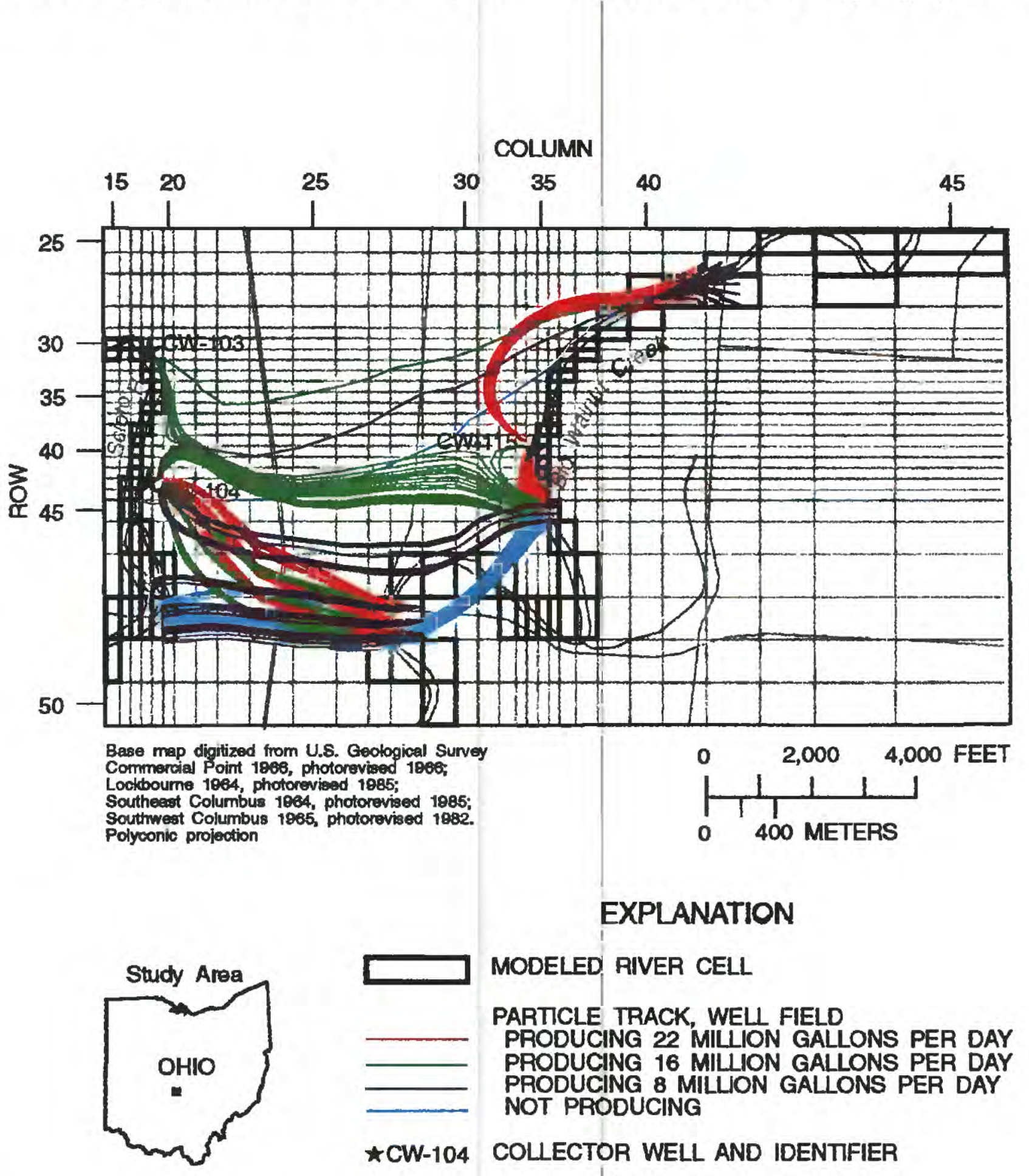

Figure 10. Loci of particles tracked from cells representing locations on Big Walnut Creek to cells representing locations on Scioto River, 1979 and 1986 steady-state simulations. 
104 in the 8-Mgal/d simulation; to $\mathrm{CW}-115, \mathrm{CW}-103$, and CW-104 in the 16-Mgal/d simulation; and to CW115 in the 22-Mgal/d simulation. Particles begun in cells near the northeastem comer of figure 10 discharge to a different location in each scenario. Average traveltimes and horizontal velocities of particles during each pumping scenario are listed in table 3.

Hydrogeologic parameters and stresses upon which the 1986 flow model is based were changed systematically and independently to determine their individual effects upon the size of the predicted CRA's and the length of roads intersected by the CRA's. The parameters included in this sensitivity analysis for the 1986 steady-state simulation were vertical hydraulic conductance between layers 1 and 2 and between layers 2 and 3; horizontal hydraulic conductivity in the glacial materials (layers 1 and 2); transmissivity of the bedrock (layer 3); porosity; recharge by precipitation; riverbed conductance; and pumping rate. In each case except the last, a pumping rate of $8 \mathrm{Mgal} / \mathrm{d}$ was used.

The results of the sensitivity analysis on the 1986 steady-state simulation are shown in tables 4 and 5. Effects of pumping rate were reported in table 2.

The factors most affecting the size of the CRA's are porosity, pumping rate, and horizontal hydraulic conductivity. The effects of porosity on CRA sizes are just as expected: as porosity decreases, the availability of water in each cell also decreases, and water from cells further away from the wells must be drawn to satisfy pumping requirements, thereby increasing CRA size. The effects of hydraulic conductivity of the glacial materials also are as expected: as hydraulic conductivity increases, the hydraulic gradient caused by the stress of pumping is decreased, and the CRA must increase in size to compensate for the decrease in gradient.

CRA sizes decrease with increases in riverbed conductance (the wells are able to draw more water from the rivers) but are not affected by decreases in riverbed conductance. This probably indicates that induced infiltration is near a minimum already, and only can improve with management practices such as dredging or increasing the available surface area for induced infiltration by adding infiltration lagoons.

Some effect of vertical hydraulic conductivity between layers 2 and 3 on the size of CRA's also is seen; this and the effects of transmissivity of layer 3 indicate that the contribution of water from bedrock to the modeled system is significant. The decrease in size of CRA's with increase in transmissivity of layer 3 indicates that less water is supplied to the well by precipitation and recharge when more water is more available from layer 3 .

Table 3. Discharge points, traveltimes, and velocities of particles started in cells representing Big Walnut Creek under four stress conditions, 1979 and 1986 steady-state simulations

[SR, Scioto River]

\begin{tabular}{|c|c|c|c|c|c|c|c|c|c|c|c|c|c|}
\hline \multicolumn{2}{|c|}{$\begin{array}{l}\text { Starting cell along } \\
\text { Big Walnut Creek }\end{array}$} & \multicolumn{3}{|c|}{ No pumping (1979) } & \multicolumn{3}{|c|}{$\begin{array}{c}\text { Pumping } 8 \text { million gallons } \\
\text { per day (1986) }\end{array}$} & \multicolumn{3}{|c|}{$\begin{array}{l}\text { Pumping } 16 \text { million gallons } \\
\text { per day (1986) }\end{array}$} & \multicolumn{3}{|c|}{$\begin{array}{l}\text { Pumping } 22 \text { million gallons } \\
\text { per day (1986) }\end{array}$} \\
\hline Row & Column & $\begin{array}{l}\text { Dis- } \\
\text { charge } \\
\text { point }\end{array}$ & $\begin{array}{l}\text { Average } \\
\text { travel- } \\
\text { time } \\
\text { (years) }\end{array}$ & $\begin{array}{c}\text { Average } \\
\text { horizon- } \\
\text { tal } \\
\text { velocity } \\
\text { (feet } \\
\text { per day) }\end{array}$ & $\begin{array}{l}\text { Dis- } \\
\text { charge } \\
\text { point }\end{array}$ & $\begin{array}{c}\text { Average } \\
\text { travel- } \\
\text { time } \\
\text { (years) }\end{array}$ & $\begin{array}{c}\text { Average } \\
\text { horizon- } \\
\text { tal } \\
\text { velocity } \\
\text { (feet } \\
\text { per day) }\end{array}$ & $\begin{array}{l}\text { Dis- } \\
\text { charge } \\
\text { point }\end{array}$ & $\begin{array}{l}\text { Average } \\
\text { travel- } \\
\text { time } \\
\text { (years) }\end{array}$ & $\begin{array}{c}\text { Average } \\
\text { horizon- } \\
\text { tal } \\
\text { velocity } \\
\text { (feet } \\
\text { per day) }\end{array}$ & $\begin{array}{l}\text { Dis- } \\
\text { charge } \\
\text { point }\end{array}$ & $\begin{array}{c}\text { Average } \\
\text { travel- } \\
\text { time } \\
\text { (years) }\end{array}$ & $\begin{array}{c}\text { Average } \\
\text { horizon- } \\
\text { tal } \\
\text { velocity } \\
\text { (feet } \\
\text { per day) }\end{array}$ \\
\hline 26 & 42 & $\begin{array}{l}\text { SR near } \\
\text { CW-104 }\end{array}$ & 58.8 & 0.57 & CW-104 & 40.7 & 0.80 & CW-103 & 25.8 & 1.21 & CW-115 & 9.9 & 1.89 \\
\hline 27 & 42 & $\begin{array}{l}\text { SR near } \\
\text { CW-104 }\end{array}$ & 57.6 & .58 & CW-104 & 39.6 & .82 & CW-103 & 24.6 & 1.26 & CW-115 & 9.2 & 1.96 \\
\hline 45 & 36 & SR & 19.3 & 1.18 & CW-104 & 16.4 & 1.35 & $\begin{array}{l}C W-115 \\
C W-103\end{array}$ & 14.6 & 1.32 & CW-115 & .42 & 8.79 \\
\hline 45 & 35 & SR & 18.4 & 1.21 & CW-104 & 15.6 & 1.37 & CW-104 & 15.9 & 1.41 & CW-115 & .44 & 8.23 \\
\hline 48 & 28 & SR & 6.8 & 1.93 & SR & 7.8 & 1.90 & CW-104 & 5.5 & 2.91 & CW-104 & 4.7 & 3.28 \\
\hline 48 & 27 & SR & 5.4 & 2.17 & SR & 6.8 & 2.02 & CW-104 & 4.6 & 3.14 & CW-104 & 4.0 & 3.58 \\
\hline
\end{tabular}


A factor that must be considered is the extent of contributing areas (not contributing recharge areas) from layer 3 to the wells. To this end, a series of simulations involving changes in transmissivity of layer 3 and vertical conductance between layers 2 and 3 were run, looking only at contributing areas in layer 3. Although the data are not shown here, the contributing areas ( 0 to 10 -year, inclusive) from layer 3 did not total more than $0.43 \mathrm{mi}^{2}$ in any of these secondary simulations. Therefore, although the wells did draw water from layer 3 in all simulations, the extent of contributing areas in layer 3 was never as great as the extent of CRA's in layer 1.

Cunningham and others (1995) report that the parameters to which the ground-water-flow model (upon which the particle tracking was based) was most sensitive include streambed conductance and decreases in horizontal hydraulic conductivity, vertical conductance, and river stage. Pumping rate was not included as a factor in the sensitivity analysis of the flow model, and porosity is a factor that is meaningful only in the particle tracking.

\section{Results of Transient Analysis}

Although the same analysis for the steady-state simulation was done for the transient simulation, the discussion of CRA's must be limited to 0 - to 5-year areas for the transient simulation because the transient model covered only a 5.2-year span. Figure 11 displays the CRA's to the wells under transient conditions for 1986-91. Average well-field production during this period was about $18.5 \mathrm{Mgal} / \mathrm{d}$; therefore, the CRA's estimated by the transient model are similar to those estimated during the 1986 steady-state simulation when the well field was producing 16 or $22 \mathrm{Mgal} / \mathrm{d}$.

The CRA's are discontinuous in several areas, most noticeably northeast of CW-101. These discontinuities are due to the changing of stresses (recharge, pumping, river stage) during the period of simulation. For example, several dry periods occurring between 1986 and 1991 were represented in the model as stress periods having no recharge. Also, during these dry periods river stage was low and water demand (especially in summer months) was high. In a steady-state

Table 4. Effects of changes in simulated vertical hydraulic and riverbed conductance on contributing recharge areas and related measurements, southern Franklin County, Ohio (steady-state simulation, March 1986)

[CRA, contributing recharge area]

\begin{tabular}{|c|c|c|c|c|c|c|c|c|c|c|c|c|c|c|c|}
\hline \multirow[t]{3}{*}{ Hydraulic property } & \multirow{3}{*}{$\begin{array}{l}\text { CRA } \\
\text { time, in } \\
\text { years }\end{array}$} & \multicolumn{7}{|c|}{ CRA, in square miles } & \multicolumn{7}{|c|}{$\begin{array}{l}\text { Length of major highways intersected by } \\
\text { CRA, in miles }\end{array}$} \\
\hline & & \multicolumn{7}{|c|}{$\begin{array}{l}\text { Multiplication factor for hydraulic } \\
\text { property }\end{array}$} & \multicolumn{7}{|c|}{$\begin{array}{l}\text { Multiplication factor for hydraulic } \\
\text { property }\end{array}$} \\
\hline & & 0.1 & 0.2 & 0.5 & 1.0 & 2.0 & 5.0 & 10 & 0.1 & 0.2 & 0.5 & 1.0 & 2.0 & 5.0 & 10 \\
\hline \multirow[t]{3}{*}{ Vertical conductance, layers 1-2 } & $0-1$ & 0.29 & 0.38 & 0.46 & 0.48 & 0.49 & 0.49 & 0.49 & 0.00 & 0.00 & 0.00 & 0.00 & 0.00 & 0.00 & 0.00 \\
\hline & $1-5$ & 1.92 & 1.91 & 1.90 & 1.90 & 1.90 & 1.90 & 1.90 & 1.92 & 1.98 & 2.06 & 2.06 & 2.06 & 2.06 & 2.06 \\
\hline & $5-10$ & 2.13 & 2.16 & 2.12 & 2.12 & 2.11 & 2.11 & 2.11 & 1.18 & 1.18 & 1.20 & 1.20 & 1.16 & 1.20 & 1.20 \\
\hline \multirow[t]{3}{*}{ Vertical conductance, layers 2-3 } & $0-1$ & 0.47 & 0.47 & 0.48 & 0.48 & 0.48 & 0.47 & 0.47 & 0.00 & 0.00 & 0.00 & 0.00 & 0.00 & 0.00 & 0.00 \\
\hline & $1-5$ & 1.77 & 1.79 & 1.84 & 1.90 & 1.95 & 1.94 & 1.91 & 1.85 & 1.83 & 1.94 & 2.06 & 2.11 & 2.08 & 2.07 \\
\hline & $5-10$ & 2.26 & 2.23 & 2.21 & 2.12 & 2.04 & 1.86 & 1.77 & 1.27 & 1.29 & 1.33 & 1.20 & 1.10 & 1.04 & 0.95 \\
\hline \multirow[t]{3}{*}{ Riverbed conductance } & $0-1$ & 0.52 & 0.51 & 0.50 & 0.48 & 0.44 & 0.37 & 0.33 & 0,00 & 0.00 & 0.00 & 0.00 & 0.00 & 0.00 & 0.00 \\
\hline & $1-5$ & 2.03 & 2.04 & 1.99 & 1.90 & 1.70 & 1.44 & 1.25 & 2.28 & 2.25 & 2.09 & 2.06 & 1.83 & 1.64 & 1.51 \\
\hline & $5-10$ & 1.95 & 1.91 & 1.95 & 2.12 & 1.98 & 1.58 & 1.43 & 1.81 & 1.43 & 1.16 & 1.20 & 1.00 & 0.46 & 0.50 \\
\hline
\end{tabular}


simulation, these parameters are not variable but are assumed to be constant. In a transient simulation, they are variable enough to cause the predicted CRA to appear discontinuous.

In the immediate vicinity of the collector wells, the rivers do not appear to act as a hydrologic boundary. This effect is due primarily to relatively low riverbed conductance, which inhibits induced infiltration to the wells. Additional factors are the close proximity of the rivers to the wells and the thickness of layer 1 (which contains the rivers) at the collector wells. As distance from the collector wells is increased, the rivers begin to act like hydrologic boundaries (seen as white areas adjacent to the rivers in figure 11).A sensitivity analysis was performed on the transient model to determine the effects of hydrogeologic inputs and stresses on the results predicted by the model. The factors included in the sensitivity analysis were the same as those included in the steady-state model with the following exceptions: specific yield (layer 1) and specific storage (layers 2 and 3 ) were added, and wellfield production rate and recharge were omitted. The results are similar to those of the steady-state model; that is, the factors to which the transient model is most sensitive include porosity, riverbed conductance, and horizontal hydraulic conductivity. The data pertaining to the sensitivity analysis of the transient model are not presented; however, the largest CRA predicted was $5.09 \mathrm{mi}^{2}$ (smallest porosity), and the smallest CRA predicted was $2.30 \mathrm{mi}^{2}$ (largest riverbed conductance). The storage terms (specific yield and specific storage) did not affect the size of CRAs in this analysis. The results were slightly sensitive to changes in vertical hydraulic conductance between layers 1 and 2 and between layers 2 and 3 .

Table 5. Effects of changes in simulated hydraulic conductivity, transmissivity, porosity, and recharge rates on contributing recharge areas and related measurements, southern Franklin County, Ohio (steady-state simulation, March 1986)

[CRA, contributing recharge area]

\begin{tabular}{|c|c|c|c|c|c|c|c|c|c|c|c|}
\hline \multirow[t]{3}{*}{ Hydraulic property } & \multirow[t]{3}{*}{$\begin{array}{c}\text { CRA } \\
\text { time, in } \\
\text { years }\end{array}$} & \multicolumn{5}{|c|}{ CRA, in square miles } & \multicolumn{5}{|c|}{$\begin{array}{l}\text { Length of major highways } \\
\text { intersected by CRA, in miles }\end{array}$} \\
\hline & & \multicolumn{5}{|c|}{$\begin{array}{l}\text { Multiplication factor for } \\
\text { hydraulic property }\end{array}$} & \multicolumn{5}{|c|}{$\begin{array}{l}\text { Multiplication factor for } \\
\text { hydraulic property }\end{array}$} \\
\hline & & 0.50 & 0.75 & 1.0 & 1.25 & 1.5 & 0.50 & 0.75 & 1.0 & 1.25 & 1.5 \\
\hline \multirow[t]{3}{*}{ Hydraulic conductivity, layers 1 and 2} & $0-1$ & 0.41 & 0.45 & 0.48 & 0.49 & 0.51 & 0.00 & 0.00 & 0.00 & 0.00 & 0.00 \\
\hline & $1-5$ & 1.32 & 1.66 & 1.90 & 2.11 & 2.26 & 1.35 & 1.37 & 2.06 & 1.98 & 2.11 \\
\hline & $5-10$ & 1.70 & 1.99 & 2.12 & 2.26 & 2.33 & 1.29 & 1.18 & 1.20 & 1.61 & 1.62 \\
\hline \multirow[t]{3}{*}{ Transmissivity, layer 3} & $0-1$ & 0.52 & 0.49 & 0.48 & 0.46 & 0.44 & 0.00 & 0.00 & 0.00 & 0.00 & 0.00 \\
\hline & $1-5$ & 2.43 & 2.13 & 1.90 & 1.72 & 1.56 & 2.44 & 2.18 & 2.06 & 1.92 & 1.75 \\
\hline & $5-10$ & 2.31 & 2.28 & 2.12 & 1.94 & 1.75 & 1.28 & 1.37 & 1.20 & 1.18 & 1.25 \\
\hline \multirow[t]{3}{*}{ Porosity, all layers } & $0-1$ & 0.94 & 0.64 & 0.48 & 0.38 & 0.32 & 0.00 & 0.00 & 0.00 & 0.00 & 0.00 \\
\hline & $1-5$ & 3.56 & 2.59 & 1.90 & 1.50 & 1.25 & 3.25 & 2.53 & 2.06 & 1.62 & 1.24 \\
\hline & $5-10$ & 1.84 & 2.18 & 2.12 & 1.88 & 1.65 & 0.90 & 1.14 & 1.20 & 1.40 & 1.30 \\
\hline \multirow[t]{3}{*}{ Recharge } & $0-1$ & 0.46 & 0.47 & 0.48 & 0.49 & 0.49 & 0.00 & 0.00 & 0.00 & 0.00 & 0.00 \\
\hline & $1-5$ & 1.76 & 1.86 & 1.90 & 1.95 & 1.99 & 1.88 & 2.00 & 2.06 & 2.00 & 1.98 \\
\hline & $5-10$ & 1.96 & 2.02 & 2.12 & 2.22 & 2.18 & 1.25 & 1.21 & 1.20 & 1.26 & 1.30 \\
\hline
\end{tabular}


The CRA's predicted when the model was run using extreme values of riverbed conductance and porosity are shown in figures $12-15$. When riverbed conductance is decreased (creating the second largest CRA of $4.79 \mathrm{mi}^{2}$ ), the lobes of the 1- to 5-year CRA tend to remain closely adjacent to the rivers (fig. 12), whereas when porosity is decreased, the lobes of the 1- to 5-year CRA spread away from the rivers (fig. 14). The abutment of the 1- to 5-year CRA on the western boundary of the modeled area is shown in figure 14.

\section{SUMMARY AND CONCLUSIONS}

Particle-tracking analysis, based on a threelayer, finite-difference ground-water-flow model constructed by Cunningham and others (1995), was used to estimate the contributing recharge areas (CRA's) of collector wells and other discharge points in southern Franklin County, Ohio. Prepumping steady-state CRA's to quarries and rivers were based on a model that simulated conditions in October 1979. Under these "historical" conditions, CRA's of quarries, Scioto River, and Big Walnut Creek accounted for about 41 percent, 47 percent, and 12 percent of the study area, respectively. Traveltimes associated with particles tracked from a few cells along Big Walnut Creek to their discharge points in cells along Scioto River were about 5 to 60 years. Steady-state conditions in March 1986 included pumpage of about $8 \mathrm{Mgal} / \mathrm{d}$ by the collector wells; under these conditions, CRA's of quarries, Scioto River, and Big Walnut Creek accounted for about 40 percent, 2 percent, and 6 percent of the study area, respectively, and the CRA's of the collector wells accounted for 34 percent. Also under these conditions, traveltimes associated with particles tracked from a few cells along Big Walnut Creek to their discharge points in cells along Scioto River were about 7 to 41 years.

The 1986 steady-state period was used to predict CRA's of the collector wells under "predictive" simulations of 16 and $22 \mathrm{Mgal} / \mathrm{d}$. Total 10-year CRA's increased from $4.5 \mathrm{mi}^{2}$ to $6.66 \mathrm{mi}^{2}$ as pumping was increased from 8 to $22 \mathrm{Mgal} / \mathrm{d}$. Sizes of the 5- to 10 year CRA's probably were underestimated because of the abutment of the CRA against the western boundary of the model, especially during the 16- and 22-Mgal/d simulations. Flowpaths from Big Walnut Creek to Sci- oto River were highly variable, depending upon the pumping rate of the well field.

A sensitivity analysis of the model was performed to ascertain the effects of changes in hydrologic parameters on the pathlines and CRA's predicted by MODPATH. Factors most affecting the sizes of CRA's were porosity, pumping rate, and horizontal hydraulic conductivity. Transmissivity of layer 3 and vertical conductance between layers 2 and 3 also affected CRA sizes, indicating the importance of the bedrock in the hydrogeologic flow system. Contributing recharge areas were sensitive to increases in riverbed conductance but not to decreases.

Because well-field production averaged 18.5 Mgal/d during a 5-year (1986-91) transient simulation, the transient, time-related CRA's were about the same size as those for the 16-Mgal/d steady-state simulation. The CRA's during the transient simulation, however, were not continuously distributed areally because of the changing stresses during the period of simulation. Factors most affecting the sizes of CRA's during the transient simulation were porosity, riverbed conductance, and horizontal hydraulic conductivity.

This study demonstrated the importance of considering transient conditions such as recharge, pumping, and river stage on a river-aquifer system that is being used as a municipal supply of water. The steadystate analysis provided information concerning sources of water to all parts of the ground-water system and the effects of unchanging variables, such as transmissivity and aquifer thickness, on contributing recharge areas. However, the transient analysis demonstrated clearly the effects of changing stresses on the predicted CRA's. All the hydrologic factors, especially those variable with time, need to be accounted for when water-supply goals for Columbus are developed.

The conductance of the riverbeds was shown to be an important factor in predicting the areal extents of the CRA's. Cunningham and others (1995), Childress and others (1991), and Moreno (1988) reported the results of many measurements of vertical hydraulic conductivity of the riverbeds. This important hydrologic factor, unlike the hydraulic conductivity of the aquifer, can change rapidly and spatially as a result of scour and deposition of sediments by usual riverine processes. Further study is needed to address methods and applications of measuring, mapping, and managing riverbed conductance. 


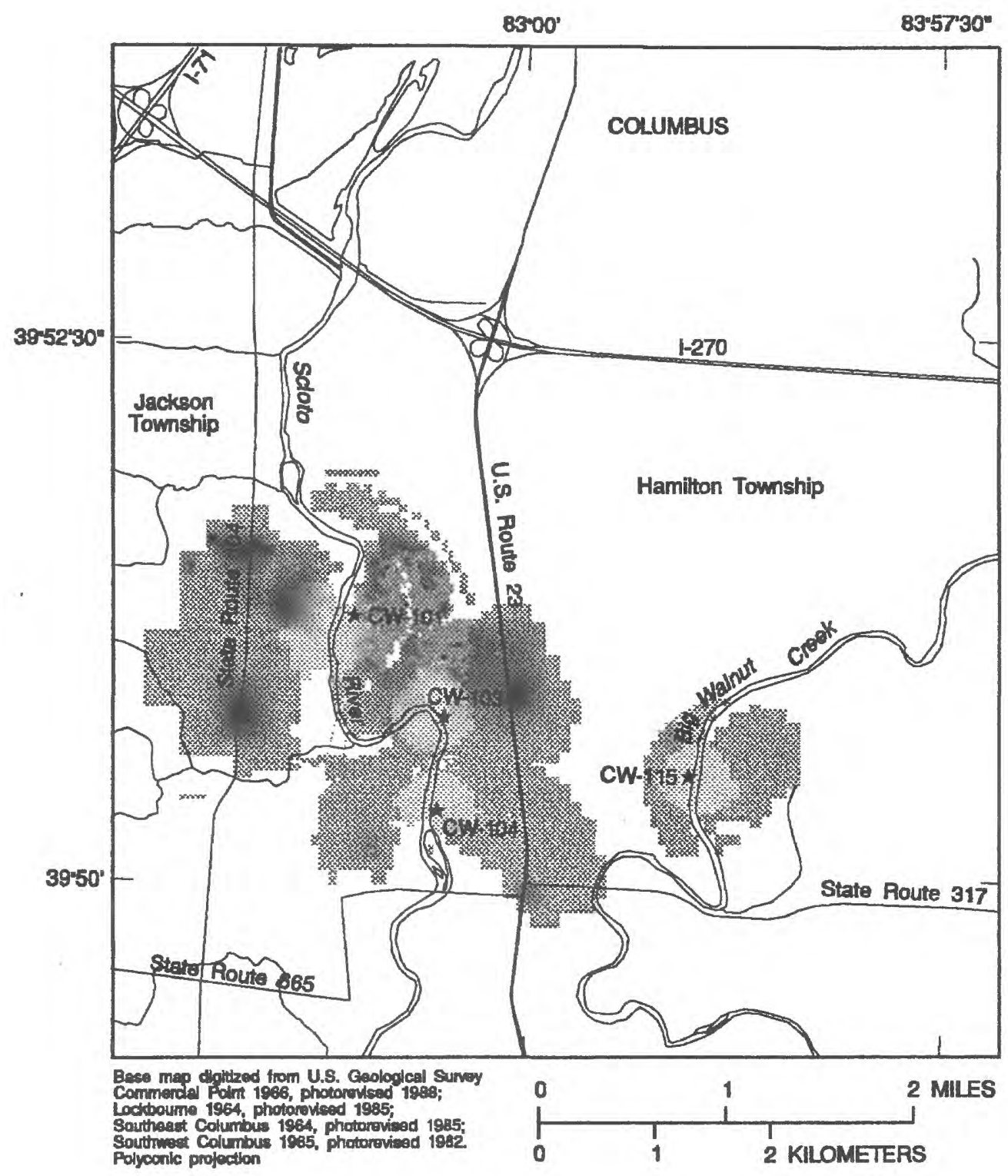

\section{EXPLANATION}

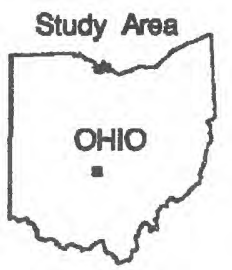

AREAS CONTRIBUTING RECHARGE TO COUECTOR WEUS

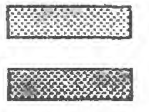

0-1 YEAR

1-5 YEAR

$\star$ CW-101 COUECTOR WEU AND IDENTIFER

Figure 11. Time-related contributing recharge areas of wells in southern Franklin County, Ohio, between March 1986 and July 1991. 


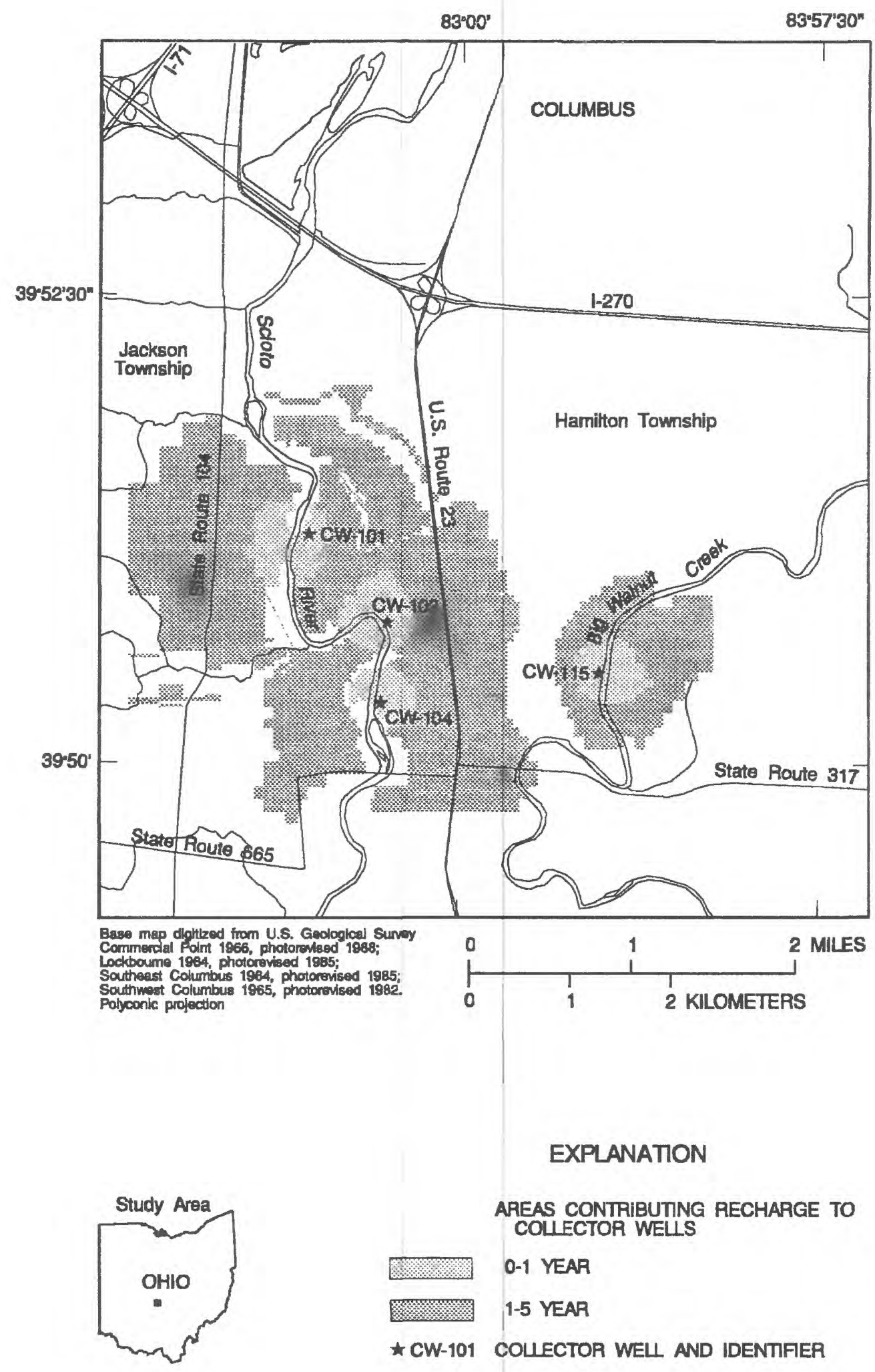

Figure 12. Time-related contributing recharge areas of wells in southern Franklin County, Ohio, between March 1986, and July 1991, when simulated riverbed conductance was decreased by a factor of 10. 


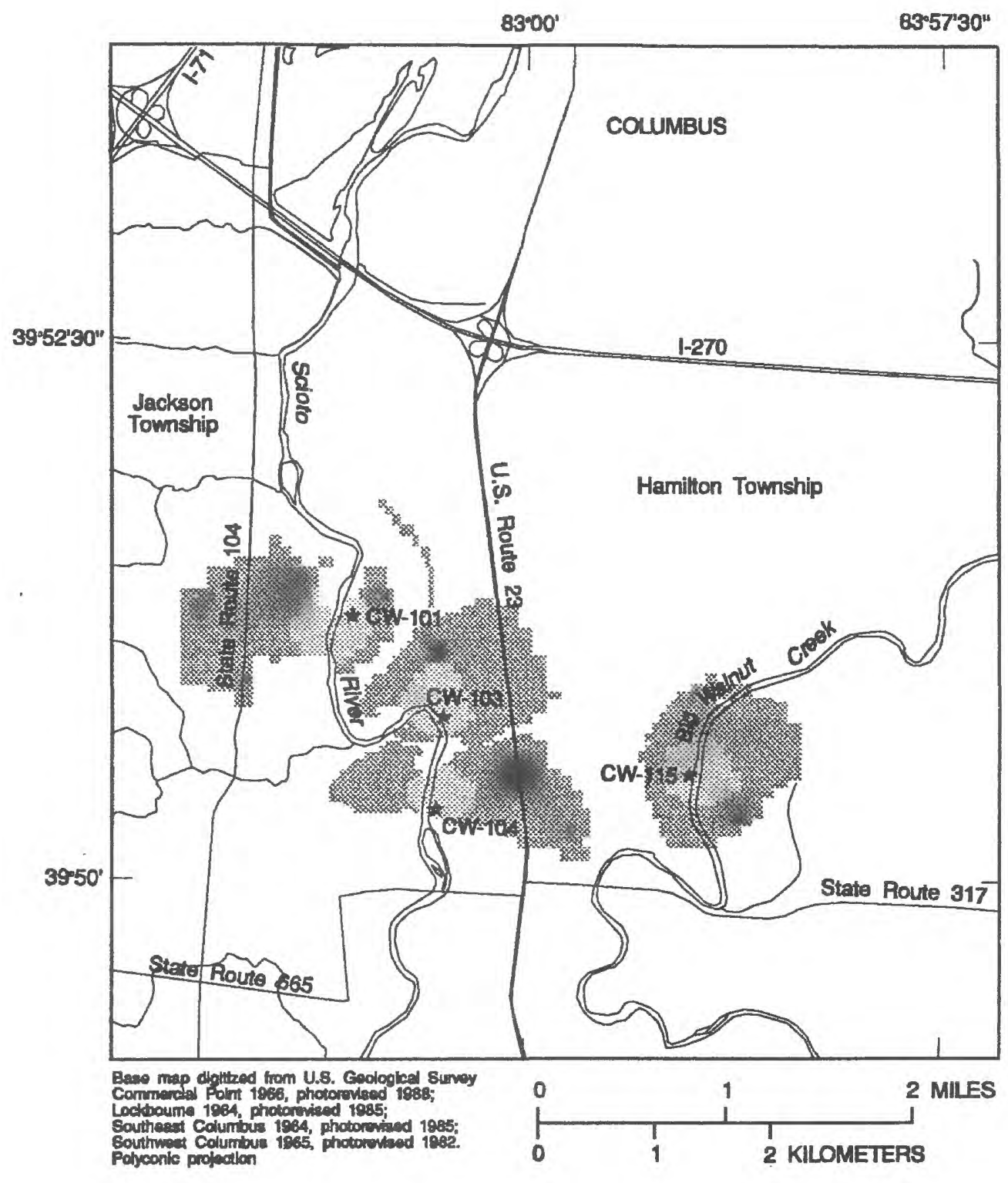

EXPLANATION

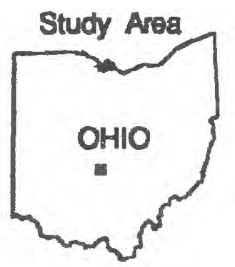

AREAS CONTRIBUTING RECHARGE TO COUECTOR WEUS

0-1 YEAR

1-5 YEAR

$\star$ CW-101 COUECTOR WEL AND IDENTIFER

Figure 13. Time-related contributing recharge areas of wells pumping in southem Franklin County, Ohio, between March 1986 and July 1991, when simulated riverbed conductance was increased by a factor of 10 . 


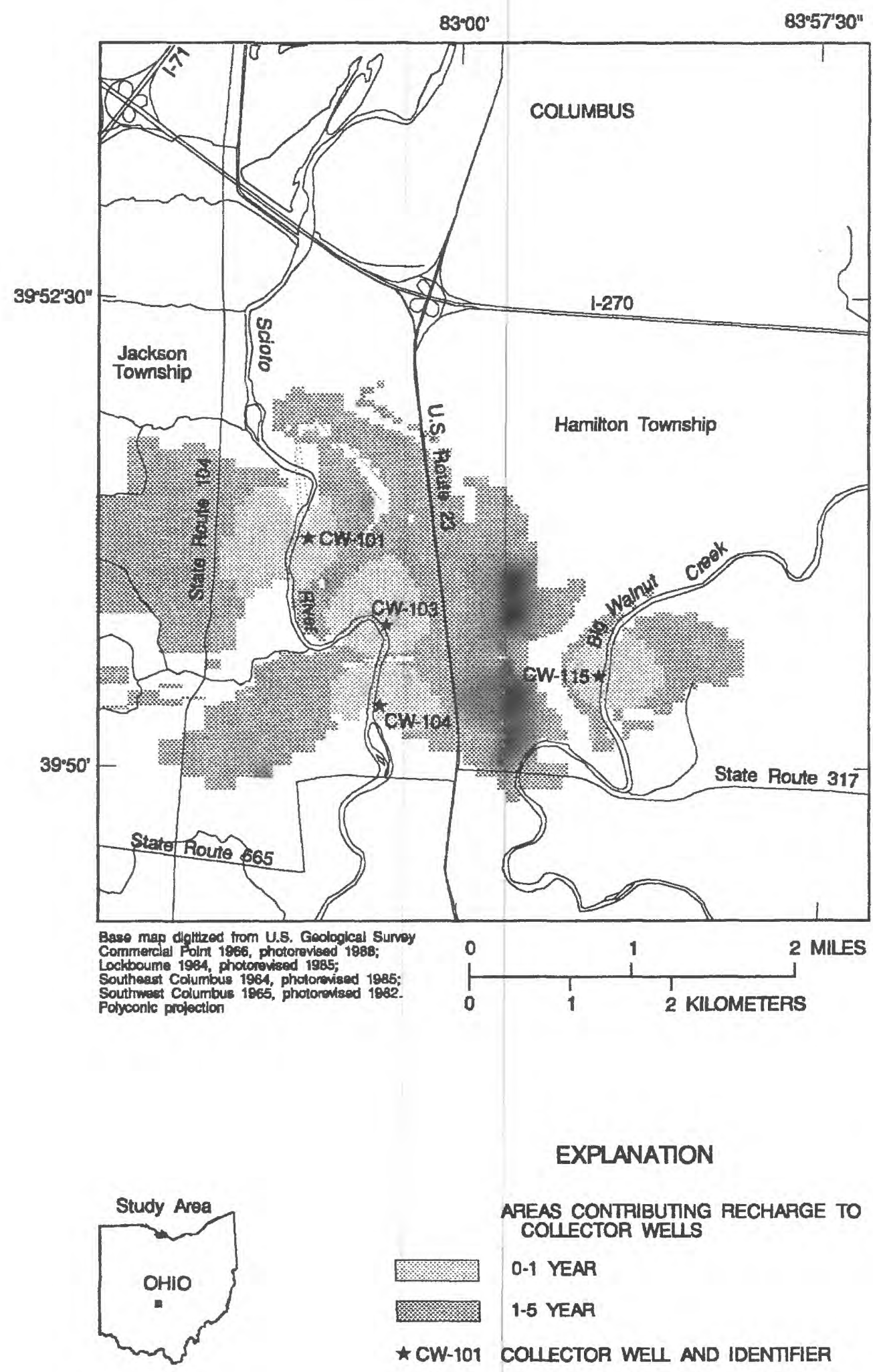

Figure 14. Time-related contributing recharge areas of wells pumping in southern Franklin County, Ohio, between March 1986 and July 1991, when simulated porosity of all aquifers was decreased 50 percent. 


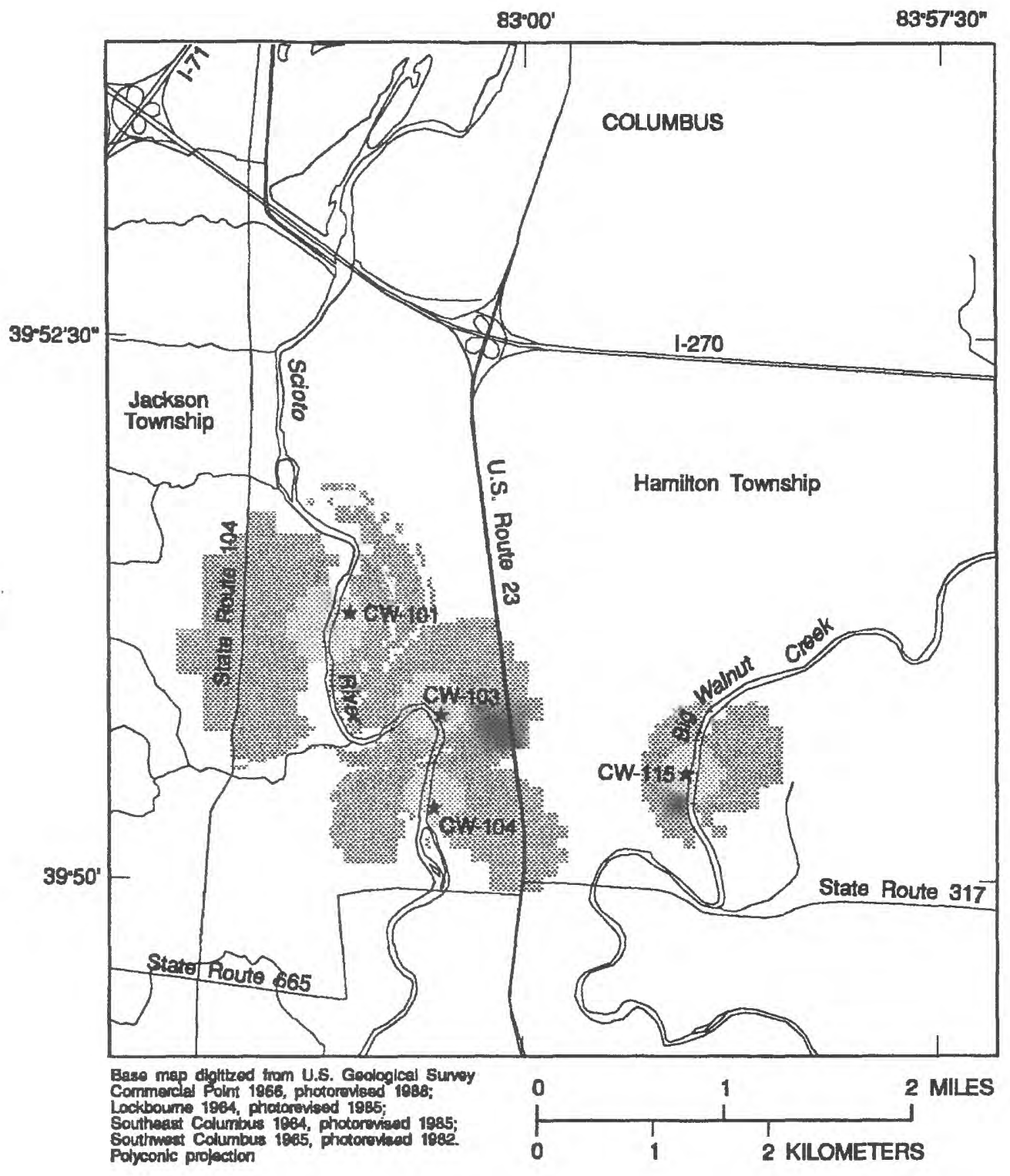

EXPLANATION

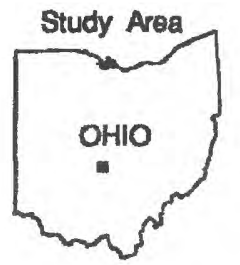

AREAS CONTRIBUTING RECHARGE TO COUECTOR WELS

0-1 YEAR

1-5 YEAR

$\star$ CW-101 COUECTOR WELL AND IDENTIFER

Figure 15. Time-related contributing recharge areas of wells pumping in southern Franklin County, Ohio, between March 1986 and July 1991, when simulated porosity of all aquifers was increased 50 percent. 


\section{REFERENCES CITED}

Bair, E.S., Sheets, R.A., and Eberts, S.M., 1990, Particletracking as a method to determine flow paths and traveltimes from hypothetical spill sites within the capture zone of a municipal well field: Ground Water, v. 28, no. 6, p. 884-892.

Childress, CJ.O., Sheets, R.A., and Bair, E.S., 1991, Hydrogeology and water quality near the south well field, southem Franklin County, Ohio, with emphasis on the simulation of ground-water flow and transport of Scioto River: U.S. Geological Survey WaterResources Investigations Report 91-4080, 78 p.

Cunningham, W.L., 1992, Hydrogeology and simulation of transient ground-water flow at the South Well Field, Columbus, Ohio: Columbus, The Ohio State University, unpublished Master's thesis, 154 p., 62 figs.

Cunningham, W.L., Bair, E.S., and Yost, W.P., 1995, Hydrogeology and simulation of ground-water flow at the South Well Field, Columbus, Ohio: U.S. Geological Survey Water-Resources Investigations Report 95$4279,56 \mathrm{p}$.

de Roche, J.T., 1985, Hydrogeology and effects of landfills on ground-water quality, southern Franklin County, Ohio: U.S. Geological Survey Water-Resources Investigations $85-4222,58 \mathrm{p}$.

de Roche, J.T., and Razem, A.C., 1981, Ground-water quality in the vicinity of landfill sites, southern Franklin County, Ohio: U.S. Geological Survey WaterResources Investigations Report 81-919, 19 p. 1984, Water quality of a stream-aquifer system, southern Franklin County, Ohio: U.S. Geological Survey Water-Resources Investigations Report 84-4238, 44 p.

Eberts, S.M., and Bair, E.S., 1990, Simulated effects of quarry dewatering near a municipal well field: Ground Water, v. 28 , no. 1, p. $37-47$.

Johnson, A.I., 1967, Specific yield-compilation of specific yields for various materials: U.S. Geological Survey Water Supply Paper 1662-D, 74 p.

Malcolm Pimie, Inc., 1988, Wellfield protection, development and management plan: Report to the city of Columbus Division of Water [variously paginated].

McDonald, M.G., and Harbaugh, A.W., 1988, A modular three-dimensional finite-difference ground-water flow model: U.S. Geological Survey Techniques of WaterResources Investigations, book 6, chap. A1, 586 p.

Meinzer, O.E., 1923, Outline of ground-water hydrology, with definitions: U.S. Geological Survey Water-Supply Paper 494, $71 \mathrm{p}$.

Moreno, R.R., 1988, Variations in streambed permeability in the Scioto River near the South Columbus wellfield and its effects on wellfield performance: Columbus, Ohio, The Ohio State University, unpublished Bachelor's thesis, $70 \mathrm{p}$.
Morrissey, D.J., 1989, Estimation of the recharge area contributing water to a pumped well in a glacial-drift, river-valley aquifer: U.S. Geological Survey WaterSupply Paper 2338, 41 p.

Ohio Environmental Protection Agency, 1992, Ohio wellhead protection program: Division of Drinking and Ground Waters, $53 \mathrm{p}$. with appendixes.

Pollock, D.W., 1994, User's guide for MODPATH/MODPATH-PLOT, version 3, a particle tracking post-processing package for MODFLOW, the U.S. Geological Survey finite-difference ground-water flow model: U.S. Geological Survey Open-File Report $94-464$ [varjously paginated].

Ranney Water Systems, Inc., 1970, Report to the city of Columbus, Ohio on ground-water feasibility evaluation, southeastern Franklin County, Ohio- hydrology: $97 \mathrm{p}$.

Razem, A.C., 1983, Simulations of nonsteady flow in a glacial aquifer, southern Franklin County, Ohio: U.S. Geological Survey Water-Resources Investigations Report 83-4022, 17 p.

Reilly, T.E., and Pollock, D.W., 1993, Factors affecting areas contributing recharge to wells in shallow aquifers: U.S. Geological Survey Water-Supply Paper $2412,21 \mathrm{p}$.

Schmidt, J.J., and Goldthwait, R.P., 1958, Ground-water resources of Franklin County: Ohio Department of Natural Resources Division of Water, Bulletin 30,97 p.

Sedam, A.C., Eberts, S.M., and Bair, E.S., 1988, Groundwater levels, water quality, and potential effects of toxic-substance spills or cessation of quarry dewatering near a municipal ground-water supply, southern Franklin County, Ohio: U.S. Geological Survey WaterResources Investigations Report 88-4138, $111 \mathrm{p}$.

Sheets, R. A., 1994, Contributing recharge areas of watersupply wells at Wright-Patterson Air Force Base, Ohio: U.S. Geological Survey Water-Resources Investigations Report 94-4231, 35 p.

Stilson, Alden E., and Associates, 1976, Report of the development of a ground-water supply in the south well field, Report to City of Columbus: [variously paginated].

Weiss, E.J., and Razem, A.C., 1980, A model for flow through a glacial outwash aquifer in southeast Franklin County, Ohio: U.S. Geological Survey WaterResources Investigations 80-56, $27 \mathrm{p}$. 